\title{
14. MIOCENE DINOCYSTS FROM DEEP SEA DRILLING PROJECT LEG 81, ROCKALL PLATEAU, EASTERN NORTH ATLANTIC OCEAN ${ }^{1}$
}

\author{
Lucy E. Edwards, U.S. Geological Survey²
}

\begin{abstract}
The biostratigraphic occurrences of dinoflagellate cysts from the Miocene sediments of DSDP Leg 81 are documented using 38 fossiliferous samples from Holes 555, 553A, 552, 552A, 554, and 554A, Rockall Plateau, eastern North Atlantic Ocean. Lower Miocene dinocysts were recovered from Hole 555, middle Miocene dinocysts from Holes 555 and 553A, and upper Miocene dinocysts from Holes 555, 552, 552A, 554, and 554A.

In the middle Miocene, important species at Leg 81 sites include: "Nematosphaeropsis" aquaeducta (lowest and highest occurrences within the middle Miocene), Tectatodinium simplex $\mathrm{n}$. comb. (lowest occurrence within the middle Miocene), Danea? sp. (lowest and highest occurrences), Labyrinthodinium truncatum (lowest and highest occurrences), Hystrichostrogylon sp. (lowest occurrence), Batiacasphaera sp. I (highest occurrence), Invertocysta tabulata n. gen., n. sp. (lowest occurrence), Invertocysta lacrymosa n. gen., n. sp. (lowest occurrence), Operculodinium sp. of Jan du Chêne (lowest occurrence), Incertae sedis sp. I (lowest occurrence), Fibrocysta? fusiforma n. sp. (lowest occurrence), and Pentadinium laticinctum (highest occurrence).

In the upper Miocene, important species from Leg 81 sites include: Incertae sedis sp. II (lowest occurrence), Fibrocysta? fusiforma n. sp., (highest occurence), and Incertae sedis sp. I (highest occurrence).

Invertocysta tabulata $\mathrm{n}$. gen., n. sp. reveals a unique and well-developed paratabulation.
\end{abstract}

\section{INTRODUCTION}

Leg 81 of the Deep Sea Drilling Project drilled eight holes at four sites in the southwestern part of the Rockall Plateau in the eastern North Atlantic Ocean (Fig. 1). This chapter deals with the biostratigraphic occurrences of dinoflagellate cysts in the Miocene sediments of this leg. The Plio-Pleistocene dinocysts are discussed by Harland (this volume) and the Paleogene dinocysts are treated by Brown and Downie (this volume).

Relatively few detailed stratigraphic studies of Miocene dinoflagellate cysts have been made. Maier (1959) and Gerlach (1961) documented ranges of selected dinoflagellate cysts in Germany and included Miocene deposits. Habib (1971) reported the occurrences of dinoflagellates across the Miocene/Pliocene boundary in northern Italy. In 1972, Habib included Miocene dinocysts in his report on the Mesozoic and Cenozoic dinoflagellates from offshore North America. Williams (1975) and Williams and Brideaux (1975) included Miocene as well as older and younger dinoflagellate material in their studies of the Grand Banks and Scotian Shelf. In his 1977 work, Williams presented a zonation of the Triassic to Pliocene, which includes three zones in the Miocene.

Manum (1976) studied the Tertiary dinocysts from the Norwegian-Greenland Sea sediments and erected a provisional zonation. Costa and Downie (1979) reported on the Cenozoic dinocysts from the Rockall Plateau and established nine informal partial-range zones. For this same leg, Harland (1979) documented the ranges of dinocysts

\footnotetext{
${ }^{1}$ Roberts, D. G., Schnitker, D., et al., Init. Repts, DSDP, 81: Washington (U.S. Govt. Printing Office),

2 Address: U.S. Geological Survey, 970 National Center, Reston, VA 22092.
}

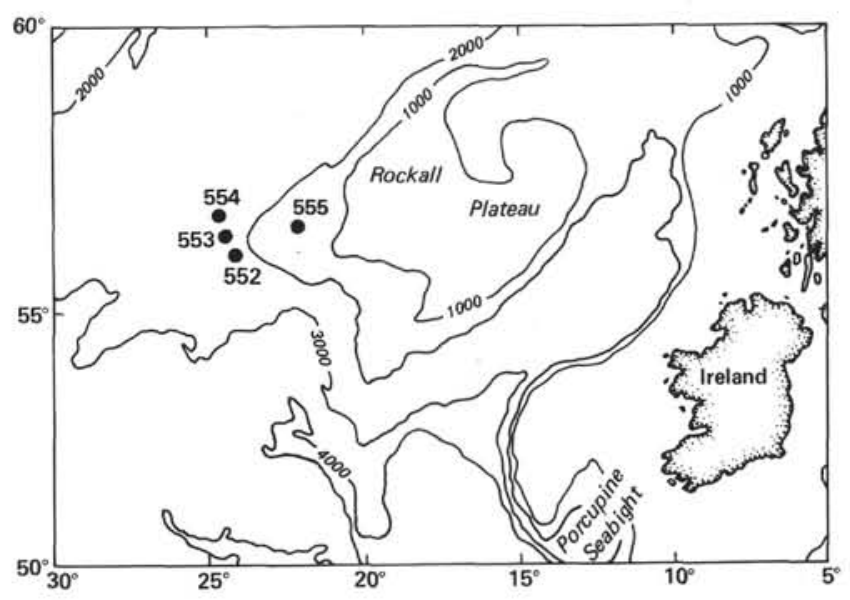

Figure 1. Map of North Atlantic showing position of sites for Leg 81 .

from the Neogene and Quaternary of the Bay of Biscay. $\mathrm{He}$, too, erected a different, tentative fourfold informal zonation. Piasecki (1980) erected four formal biozones based on successive first occurrences and documented the dinoflagellate cyst biostratigraphy in the Miocene of Denmark. In this chapter, the observed dinocyst ranges for the Miocene are given, but no formal or informal zonation is introduced.

\section{METHODS}

Six of the eight holes drilled on Leg 81 recovered Miocene sediments. From these, 54 samples were taken for dinoflagellates, 38 of which contained identifiable dinocysts. Samples $\left(10-40 \mathrm{~cm}^{3}\right.$ of sediment) were treated with hydrochloric and hydrofluoric acids, oxidized with nitric acid, separated by floating in heavy liquid $\left(\mathrm{ZnCl}_{2}\right.$, sp. gr. 1.8 ) if there was sufficient residue or by swirling if there was little residue, and stained with Bismark brown. All samples were observed by light microscope using Nomarski interference contrast. In addition, two samples $(555-22-1,107-109 \mathrm{~cm}$ and $555-21-2,60-62 \mathrm{~cm})$ were ex- 
amined using the scanning electron microscope (SEM). All processed and bulk material is housed at the U.S. Geological Survey palynology collection in Reston, Virginia. All microscope slide coordinates used in the text, systematic descriptions, and plate captions are given for Olympus microscope $201526^{3}$ held by a specially milled metal insert.

\section{RESULTS}

The dinocysts from Leg 81 are discussed by site, in order of decreasing age of recovered dinocysts. Site 555 (Fig. 2) is by far the most complete and contains assemblages of early, middle, and late Miocene age. Site 553 (Fig. 3) yielded middle Miocene dinoflagellates and one sample of late Miocene/early Pliocene age. Site 552 (Fig. 4) and Site 554 (Fig. 5) yielded late Miocene dinocysts. In the discussions and the accompanying charts, the ages given are those determined by Leg 81 micropaleontologists (see Backman et al., this volume). Dinocyst preservation ranges from good to poor. In many samples, dinocyst recovery was sparse; usually less than $100 \mathrm{spec}-$ imens were observed per slide.

\section{Site 555}

The most complete Miocene section in this study comes from Hole 555 , drilled at $56^{\circ} 33.70^{\prime} \mathrm{N}, 20^{\circ} 46.93^{\prime} \mathrm{W}$, at a water depth of $1659 \mathrm{~m}$ in the southwestern part of the Rockall Plateau. This site was the most landward and the shallowest of the four Leg 81 sites. Twenty-one samples were taken and all included dinocysts. The highest sample (555-3-7, 40-42 cm) contained only rare reworked Paleogene specimens. The dinocyst occurences from Hole 555 are shown in Figure 2.

Only two samples (555-26-3, 50-52 cm and 555-25-4, $70-72 \mathrm{~cm}$ ) are from the early Miocene, and these contain species such as Lingulodinium machaerophorum (Deflandre and Cookson) Wall, Nematosphaeropsis labyrinthea (Ostenfeld) Reid, Batiacasphaera sp. I (Plate 1, Fig. 2), B. sphaerica Stover, Hystrichosphaeropsis obscura Habib, Operculodinium sp. of Piasecki, 1980 (Plate 5, Fig. 3) and ?Cannosphaeropsis sp. b of Shimakura et al., 1971 (Plate 1, Fig. 4). The highest occurrence of Systematophora placacantha (Deflandre and Cookson) Davey et al. is found in the lowest middle Miocene (555-24-3, 70-72 cm).

In the middle Miocene, several forms are potentially diagnostic. Nine have their lowest occurrences within the lower part of the middle Miocene: Impagidinium patulum (Wall) Stover and Evitt, Spiniferites mirabilis (Rossignol) Sarjeant, “Nematosphaeropsis" aquaeducta Piasecki, "gen. et sp. indet." of Piasecki, 1980 (Plate 5, Fig. 7), Tectatodinium simplex (Harland) n. comb., Danea? sp. (Plate 4, Fig. 1, Plate 5, Figs. 4-6), Labyrinthodinium truncatum Piasecki, Hystrichostrogylon $\mathrm{sp}$. (Plate 1, Fig. 7), and Batiacasphaera sp. II (Plate 1, Fig. 8). The two unnamed species of Batiacasphaera have their highest occurrences within the middle Miocene. First occurring within the middle Miocene are Invertocysta tabulata n. gen., n. sp. (Plate 3, Fig. 3), Invertocysta lacrymosa n. gen., n. sp. (Plate 3, Figs. 4, 5), Operculodinium sp. of Jan du Chêne, 1977 (Plate 2, Fig. 3), Incer-

\footnotetext{
${ }^{3}$ Any use of trade names in this chapter is for descriptive purposes only and does not constitute endorsement by the U.S. Geological Survey.
}

tae sedis sp. I (Plate 3, Figs. 7, 8), Fibrocysta? fusifor$m a$ n. sp. (Plate 4, Figs. 2, 3) and Polykrikos? (Plate 4, Fig. 4). Apparently, Pentadinium laticinctum Gerlach, Dapsilidinium pseudocolligerum (Stover) Bujak et al., and Labyrinthodinium truncatum do not range into the late Miocene in this core, and Hystrichosphaeropsis obscura, Palaeocystodinium golzowense Alberti, and Operculodinium sp. of Piasecki, 1980 just barely range into the late Miocene. The middle Miocene in Hole 555 is within the Nematosphaeropsis aquaeducta Zone of Piasecki (1980).

In the upper Miocene of this hole, three new forms were recognized which may prove biostratigraphically valuable. These are Fibrocysta? fusiforma n. sp. and Incertae sedis sp. I, which first appear high in the middle Miocene and last appear in the lower part of the upper Miocene, and Incertae sedis sp. II (Plate 3, Fig. 6) which first appears within the upper Miocene.

Reworked Paleogene specimens were observed in three samples in Hole 555: Samples 555-16-5, 50-52 cm; $555-7-6,44-48 \mathrm{~cm}$; and $555-3-7,40-42 \mathrm{~cm}$.

\section{Site 553}

Site 553 lies on the western margin of the Rockall Plateau (Fig. 1), $56^{\circ} 05.32^{\prime} \mathrm{N}, 23^{\circ} 20.61^{\prime} \mathrm{W}$, at a water depth of $2329 \mathrm{~m}$. Three holes were drilled at this site, but Miocene sediments were recovered from only one, Hole 553A. Seven samples within the Miocene interval were processed for dinoflagellates. Three samples contain dinocysts, but two of these have very sparse floras. The forms found and their stratigraphic occurrences are shown in Figure 3.

In Hole 553A, Sample 553A-8-3, 32-36 cm contains the middle Miocene species "Nematosphaeropsis" aquaeducta. Sample 553A-7-3, 130-134 cm contains a representative middle Miocene flora including Batiacasphae$r a$ sp. I, Pentadinium laticinctum, Palaeocystodinium golzowense, and Hystrichostrogylon sp. The flora is thus approximately correlative with the middle part of the middle Miocene in Hole 555. Sample 553A-3-2, 80-82 cm contains Operculodinium sp. of Piasecki, 1980, which in Hole 555 does not range above the lower part of the upper Miocene.

\section{Site $\mathbf{5 5 2}$}

Site 552 lies on the western margin of the Rockall Plateau, $56^{\circ} 02.56^{\prime} \mathrm{N}, 23^{\circ} 13.88^{\prime} \mathrm{W}$, at a water depth of $2301 \mathrm{~m}$, in proximity of Site 404 from Leg 48 . Two holes were cored at Site 552: Hole 552, which was rotary cored, and Hole 552A, which was hydraulically piston cored. Seven samples in the Miocene interval were taken from Hole 552, three of which contained dinocysts; twelve samples were taken from Hole 552A, seven of which contained dinocysts. Dinocysts are not abundant at Site 552 , and the lower part of the Miocene section in both Holes 552 and 552A (middle Miocene) did not yield dinoflagellate cysts. Figure 4 is the combined occurrence chart for this site.

Samples that contain dinocysts from Site 552 contain a late Miocene assemblage comparable to that found on Site 555. Important forms include: Invertocysta tabula- 


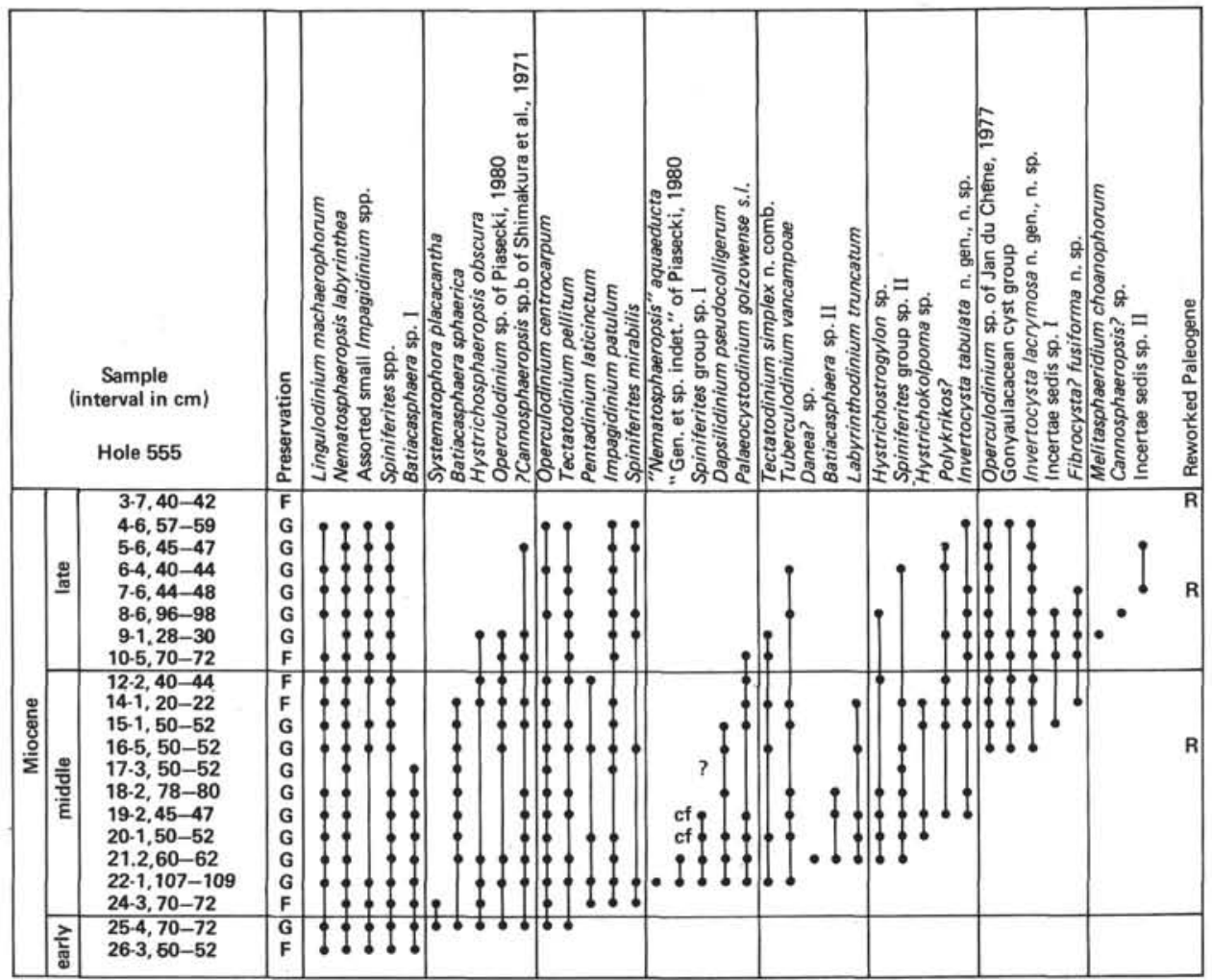

Figure 2. Range and distribution chart of dinoflagellate cysts recovered from Miocene sediments of Hole 555. Preservation: $\mathrm{P}=$ poor; $\mathrm{F}=$ fair; $\mathrm{G}=$ good. Age determinations from Leg 81 micropaleontologists.

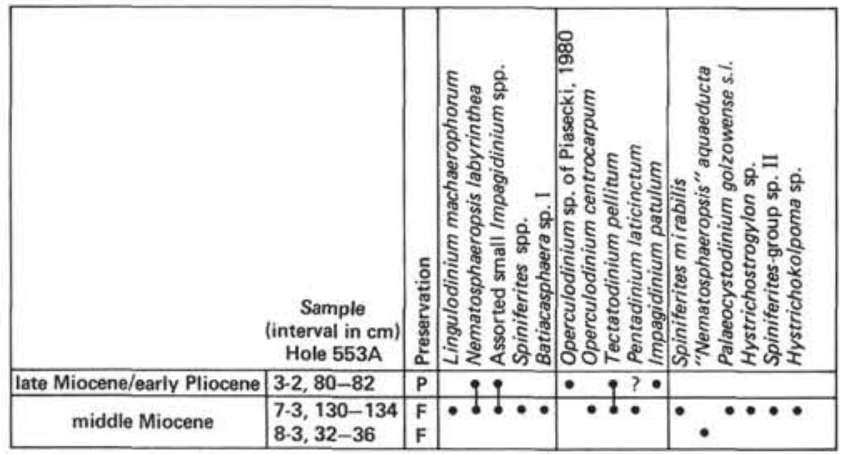

Figure 3. Range and distribution chart of dinoflagellate cysts recovered from Miocene sediments in Hole 553A. Preservation: $\mathrm{P}=$ poor; $\mathrm{F}=$ fair; $\mathrm{G}=$ good. Age determinations from Leg $81 \mathrm{mi}-$ cropaleontologists.

ta n. gen., n. sp., Invertocysta lacrymosa n. gen., n. sp., Fibrocysta? fusiforma n. sp., Polykrikos?, and Incertae sedis sp. II. Reworked Paleogene material was found in Sample 552A-32-1, 80-84 cm.

\section{Site 554}

Site 554 is on the outer high on the western edge of the Rockall Plateau, $56^{\circ} 17.41^{\prime} \mathrm{N}, 23^{\circ} 31.69^{\prime} \mathrm{W}$, at a water depth of $2574 \mathrm{~m}$. Two holes were cored at this site, Holes 554 and 554A. Three samples from the late Miocene were examined from Hole 554; all contained dinocysts. From Hole 554A, four samples were examined but

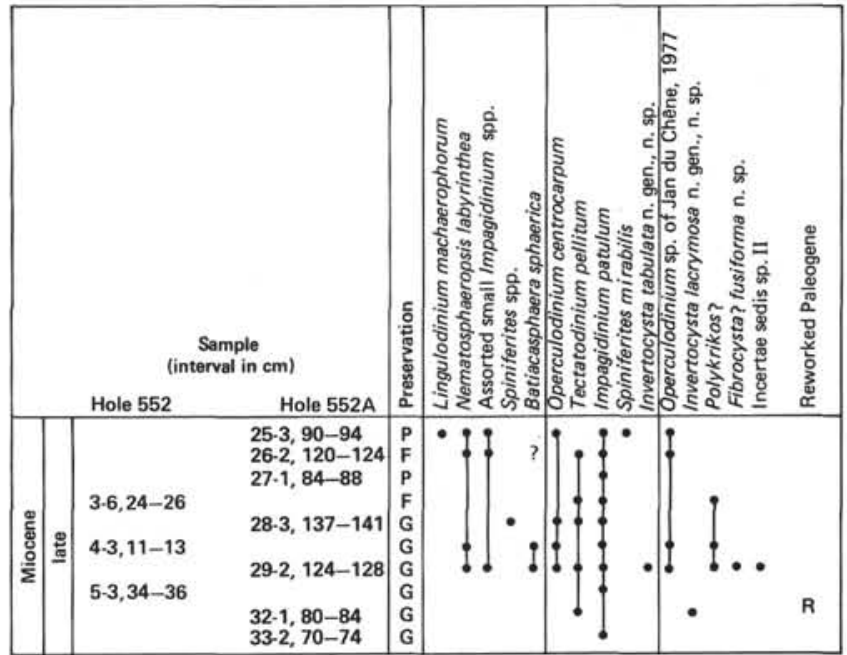

Figure 4. Range and distribution chart of dinoflagellate cysts recovered from Miocene sediments of Holes 552 and 552A. Preservation: $P=$ poor; $F=$ fair; $G=$ good. Age determinations from Leg 81 micropaleontologists.

only the upper sample, also late Miocene, contained dinocysts. Figure 5 is the combined occurrence chart for Holes 554 and 554A.

The samples from Site 554 contain a late Miocene assemblage comparable with that found in upper Miocene sediments at Sites 555 and 552. Important forms include: 


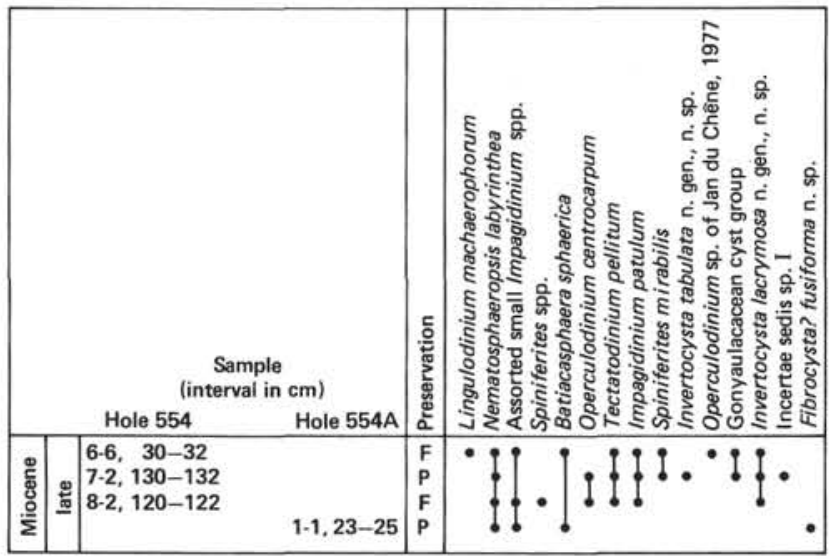

Figure 5. Range and distribution chart of dinoflagellate cysts recovered from Miocene sediments in Holes 554 and 554A. Preservation: $\mathrm{P}=$ poor; $\mathrm{F}=$ fair; $\mathrm{G}=$ good. Age determinations from Leg 81 micropaleontologists.

Invertocysta tabulata $\mathrm{n}$. gen., n. sp., Invertocysta lacrymosa n. gen., n. sp., Fibrocysta? fusiforma n. sp., and Incertae sedis sp. I.

\section{ZONAL COMPARISONS}

Comparison of the Rockall Plateau material with other Miocene material is difficult because so little is known about the ranges of Miocene dinocysts. The middle Miocene at Sites 555 and 553 is within the Nematosphaeropsis aquaeducta Zone of Piasecki (1980) recognized from the Hodde Formation in Denmark. Piasecki's upper Miocene zones, his Achomosphaera andalousiensis and Dinopterygium verriculum Zones, were not recognized in the Rockall Plateau material. Costa and Downie (1979) used an informal partial-range zone, their Zone VIII, for the middle and late Miocene and the Pliocene. The base of this zone corresponds to the base of Impagidinium patulum (=Leptodinium patulum) and "Nematosphaeropsis" aquaeducta (= Leptodinium sp. V). Jan du Chêne (1977) used the highest occurrence of Hystrichosphaeropsis obscura to mark the top of the Miocene. For an unknown reason, this species has its last appearance somewhat lower in the Rockall material. Study of additional Miocene material may better establish dinocyst ranges.

\section{CONCLUSIONS}

For the documentation of the ranges of important dinocysts in the North Atlantic, Site 555 provides a nearly complete middle and upper Miocene section, as well as a short lower Miocene part. The occurrence data from Sites 552,553 , and 554 supplement Site 555 for the middle and upper Miocene.

In the middle Miocene, important species at Leg 81 sites include: "Nematosphaeropsis" aquaeducta (lowest and highest occurrences within the middle Miocene), Tectatodinium simplex $\mathrm{n}$. comb. (lowest occurrence within the middle Miocene), Danea? sp. (lowest and highest occurrences), Labyrinthodinium truncatum (lowest and highest occurrences), Hystrichostrogylon sp. (lowest oc- currence), Batiacasphaera sp. I (highest occurrence), Operculodinium sp. of Jan du Chêne, 1977 (lowest occurrence), Invertocysta tabulata n. gen., n. sp. (lowest occurrence), Invertocysta lacrymosa n. gen., n. sp. (lowest occurrence), Incertae sedis sp. I (lowest occurrence), $\mathrm{Fi}$ brocysta? fusiforma n. sp. (lowest occurrence), and Pentadinium laticinctum (highest occurrence).

In the upper Miocene, important species from Leg 81 sites include: Fibrocysta? fusiforma n. sp. (highest occurrence), Incertae sedis sp. I (highest occurrence), and Incertae sedis sp. II (lowest occurrence).

\section{SYSTEMATIC DESCRIPTIONS}

\section{Division PYRROPHYTA Pascher, 1914 \\ Class DINOPHYCEAE Fritsch, 1935 \\ Order PERIDINIALES Haeckel, 1894 \\ Genus BATIACASPHAERA Drugg, 1970}

Batiacasphaera sphaerica Stover, 1977 (Plate 1, Fig. 1)

\section{Batiacasphaera sp. I} (Plate 1, Fig. 2)

Remarks. This form has an apical archeopyle, accessory sutures suggesting six precingular paraplates, and a surface ornamented with raised bumps and irregular discontinuous ridges. Diameter ranges from about 40 to $70 \mu \mathrm{m}$. Deep in Hole 555, the specimens are larger than average and ornament is more irregular. A typical specimen is shown in Plate 1, Figure 2.

\section{Batiacasphaera sp. II}

(Plate 1, Figs. 8A,B)

Remarks. This form is spherical with an apical archeopyle. The wall consists of a single spongy layer, often covered with numerous nontabular bumps $1-3 \mu \mathrm{m}$ in height. Specimens average $37 \mu \mathrm{m}$ in diameter (range 27-52 $\mu \mathrm{m}$ ) and the wall thickness ranges from 1.5 to $4.5 \mu \mathrm{m}$. The form is very abundant in Sample $555-19-2,45-47 \mathrm{~cm}$.

\section{Genus CANNOSPHAEROPSIS O. Wetzel, 1933}

Cannosphaeropsis? sp.

(Plate 1, Figs. 5A,B,C)

Remarks. Although only three specimens of this form were observed, the nature of the trabeculae warrants discussion. Here, the trabeculae do not represent extensions of the triradiate tips of gonal processes as in the typical Nematosphaeropsis; rather, they appear to represent normal parasutural septa that are incomplete or excavated to give the appearance of trabeculae. Pending reevaluation of the genera Nematosphaeropsis and Cannosphaeropsis, this form is questionably placed in Cannosphaeropsis.

\section{?Cannosphaeropsis sp. b of Shimakura, Nishida, and Matsuoka, 1971 \\ (Plate 1, Fig. 4)}

?Cannosphaeropsis sp. b Shimakura, Nishida, and Matsuoka, 1971, pl. 1, fig. 15, not fig. 17.

Cannosphaeropsis sp. A Williams and Brideaux, 1975, pl. 17, fig. 10. Impletosphaeridium sp. I Manum, 1976, pl. 6, figs. 8,9.

Impletosphaeridium sp. I of Manum 1976, Harland, 1978, pl. 2, figs. 6-8. Impletosphaeridium sp. I, Manum, 1976, Costa and Downie, 1979, pl. 3 , fig. 8 .

Cannosphaeropsis sp. A of Williams and Brideaux, 1975, Bujak and Davies, 1981, pl. 1, figs. 7-9.

Remarks. This distinctive form has been reported from several high latitude locations in the North Atlantic, North Pacific, and Arctic oceans. Morphologic details have not been determined but this form is probably more closely related to Melitasphaeridium than to Cannosphaeropsis. 


\section{Genus DANEA Morgenroth, 1968}

Danea? sp.

(Plate 4, Figs. 1A,B,C; Plate 5, Figs. 4-6)

Remarks. This form has a gonyaulacacean paratabulation and a 3 "archeopyle. Paratabulation is expressed by penitabular ridges that are incomplete bordering the paracingulum. This form is questionably placed in Danea because of its spherical rather than elongate shape and because it lacks any sort of apical projection.

Genus DAPSILIDINIUM Bujak et al., 1980

Dapsilidinium pseudocolligerum (Stover, 1977) Bujak et al., 1980 (Plate 1, Fig. 6)

Genus FIBROCYSTA Stover and Evitt, 1978

Fibrocysta? fusiforma n. sp.

(Plate 4, Figs. 2, 3A,B)

Holotype. Plate 4, Figure 2, slide R 2712 BJ (2), $33.7 \times 77.4$, Sample 555-7-6, 44-48 cm.

Derivation of name. Latin, spindle shaped.

Diagnosis. Cyst fusiform, autophragm only; surface smooth with many (15-40), smooth nontabular processes; paratabulation presumably gonyaulacacean, indicated by pentagonal $3^{\prime \prime}$ precingular archeopyle and faint alignment of processes in paracingular region; operculum free; dimensions of holotype, length $75 \mu \mathrm{m}$, width $47 \mu \mathrm{m}$, processes $10-13 \mu \mathrm{m}$.

Description. Cyst fusiform, with elongate rounded protrusion at apex, pointed nubbin, with or without additional spine at antapex; wall thin, autophragm only, surface smooth with 15-40 (typically 20-30) smooth nontabular processes; processes are typically acuminate, may be bifid, especially at paracingulum; processes hollow at bases, probably solid distally, paratabulation presumably gonyaulacacean, indicated by archeopyle and faint alignment of processes at paracingular region; archeopyle five-sided, type $\mathrm{P}, 3^{\prime \prime}$ only, operculum free.

Dimensions. Length, average $73 \mu \mathrm{m}$, range $65-81 \mu \mathrm{m}$; width, average $41 \mu \mathrm{m}$, range $35-52 \mu \mathrm{m}$; length of spines, $7-13 \mu \mathrm{m} ; 16$ specimens measured.

Remarks. This species is provisionally placed in Fibrocysta because the processes and the autophragm are smooth rather than fibrous.

Occurrence. Lower part of upper Miocene in Holes 555, 552A, and $554 \mathrm{~A}$.

Genus HYSTRICHOKOLPOMA Klumpp, 1953

Hystrichokolpoma sp.

(Plate 1, Fig. 3)

Remarks. A few specimens of a small delicate Hystrichokolpoma were found in the material from the Rockall Plateau.

Genus HYSTRICHOSPHAEROPSIS Deflandre, 1935

Hystrichosphaeropsis obscura Habib, 1972

(Plate 1, Fig. 10)

Genus HYSTRICHOSTROGYLON Agelopoulos, 1964

Hystrichostrogylon sp.

(Plate 1, Figs. 7A,B,C)

Remarks. Specimens from the Rockall Plateau show large ventral pericoels, often have spines on the periphragm wall, and may or may not have intergonal processes in addition to the typical gonal processes.

\section{Genus IMPAGIDINIUM Stover and Evitt, 1978}

\section{Impagidinium patulum (Wall, 1967) Stover and Evitt, 1978}

(Plate 1, Figs. 11A,B)

Remarks. In the Rockall material, the size of this species is highly variable (length ranges from 40 to $110 \mu \mathrm{m}$ ). A typical specimen is shown in Plate 1, Figures 11A,B.

\section{Impagidinium spp.}

(Plate 1, Figs. 12A,B)

Remarks. Small specimens of Impagidinium (probably several species) were found in the Rockall material, typically $30 \mu \mathrm{m}$ or less. Septa are high relative to cyst body size. No attempt was made in the present study to differentiate them. A typical specimen is illustrated in Plate 1, Figures 12A,B.

\section{Genus INVERTOCYSTA n. gen.}

Derivation of name. Latin, invertere, to turn inside out or upside down.

Diagnosis. Cyst cavate; endocyst ovoidal to ellipsoidal, often with a short apical boss; pericyst discoidal or bowl-shaped, meridionally placed, open towards dorsal side; endophragm and periphragm appressed midventrally, periphragm extended outward elsewhere; wall surfaces smooth except for parasutural ridges or thickenings of the periphragm indicating paratabulation; paratabulation gonyaulacacean, $4^{\prime}, 6^{\prime \prime}, 4-6 \mathrm{c}, 5-6^{\prime \prime \prime}, 1 \mathrm{p}, 1^{\prime \prime \prime}, ? 3-5 \mathrm{~s}$ for Invertocysta tabulata, probably similar formula for $I$. lacrymosa but incompletely expressed; archeopyle precingular, type $\mathrm{P}, 3^{\prime \prime}$ only; distribution of periphragmal paraplates asymmetrical such that most or all of the dorsal surface represents $3^{\prime \prime}$ and is absent, and the dorsal part of the paracingulum is displaced towards the antapex; up to five small paraplates may be distinguished in the parasulcal region.

Type species. Invertocysta tabulata $\mathrm{n}$. sp.

Comparisons. In the genus Invertocysta, the bowl- or saucershaped periphragm opens toward the dorsal side and is appressed to the endophragm midventrally. In Thalassiphora, the "bowl" of the periphragm opens ventrally and is attached middorsally. Stephodinium has a periphragmal extension which is positioned equatorially, rather than meridionally as in Invertocysta. Hystrichostrogylon has gonal processes and the wall layers are appressed middorsally. Invertocysta is probably related to Amiculosphaera, although in Amiculosphaera, the periphragm is appressed to the endophragm over most of the hypocyst.

Invertocysta tabulata $\mathbf{n} . \mathbf{s p}$.

(Plate 3, Figs. 3A,B; Text-Fig. 6)

Forma A (="Thalassiphora delicata") Costa and Downie, 1979, pl. 3, fig. 9 .

Holotype. Plate 3, Figures 3A,B, slide R 2712 BC (2), $35.5 \times$ 103.3 , sample $555-15-1,50-52 \mathrm{~cm}$.

Derivation of name. Latin, tabulatus, boarded, plated.

Diagnosis. Cyst cavate; endocyst ovoidal to ellipsoidal with apical boss; pericyst discoidal, meridionally placed, with endophragm and periphragm in contact midventrally; wall surface smooth or nearly smooth with well-developed parasutural ridges; paratabulation gonyaulacacean, $4^{\prime}, 6^{\prime \prime}, 4-6 \mathrm{c}, 5-6^{\prime \prime \prime}, 1 \mathrm{p}, 1^{\prime \prime \prime}, ? 3-5 \mathrm{~s}$; archeopyle precingular, type $\mathrm{P}, 3^{\prime \prime}$ only; distribution of paraplates such that nearly all of the dorsal area of the periphragm represents $3^{\prime \prime}$ and is missing (see Fig. 6) and the dorsal part of the paracingulum is displaced to form the antapical margin of the pericyst; up to five small paraplates may be distinguished in the parasulcal region; dimensions of holotype, pericyst length $90 \mu \mathrm{m}$, pericyst width $92 \mu \mathrm{m}$, endocyst length $54 \mu \mathrm{m}$, endocyst width $37 \mu \mathrm{m}$.

Description. Cyst cavate; endocyst ovoidal to ellipsoidal with small but prominent apical protrusion; pericyst discoidal, meridionally located with endocyst centered within pericyst, and endophragm and periphragm in contact in the midventral region and separated elsewhere; wall surfaces smooth to shagreenate; paratabulation indicated by low parasutural ridges, gonyaulacacean, $4^{\prime}, 6^{\prime \prime}, 4-6 C, 5-6^{\prime \prime \prime} 1 \mathrm{p}$, $1^{\prime \prime \prime}$, ?3-5s, well expressed where periphragm extends out from endophragm, well to poorly expressed midventrally (with younger specimens showing less definition in the midventral area than older specimens); paratabulation asymmetrical such that all of the pericyst tabulation is expressed on the ventral surface and what would be the dorsal side is missing; paracingulum displaced antapically so that what would normally be in the middorsal portion lies along the antapical margin and the paracingulum forms a characteristic eccentric circle on the ventral hypocyst; archeopyle precingular, type $\mathrm{P}, 3^{\prime \prime}$ only in endocyst, presumably the missing dorsal side of the pericyst also represents $3^{\prime \prime}$; up to five small paraplates may be distinguished in the parasulcal region.

Dimensions. Outer diameter, average $89 \mu \mathrm{m}$, range 63-113 $\mu \mathrm{m}$; endocyst length, average $46 \mu \mathrm{m}$, range 37-58 $\mu \mathrm{m}$; endocyst width, average $37 \mu \mathrm{m}$, range $31-60 \mu \mathrm{m} ; 25$ specimens measured.

Remarks. The discoidal shape, the prominent paratabulation, and the eccentric circle formed by the paracingulum distinguish this species from $I$. lacrymosa. This species only superficially resembles Thalassiphora delicata Williams and Downie, 1966, as emended by Eaton, 


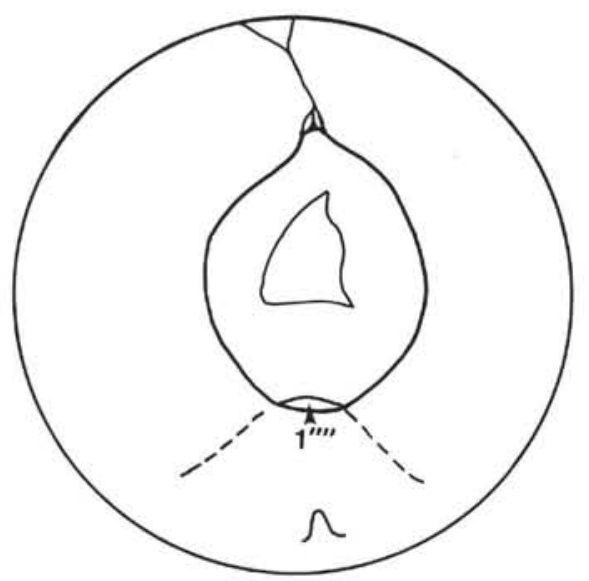

A

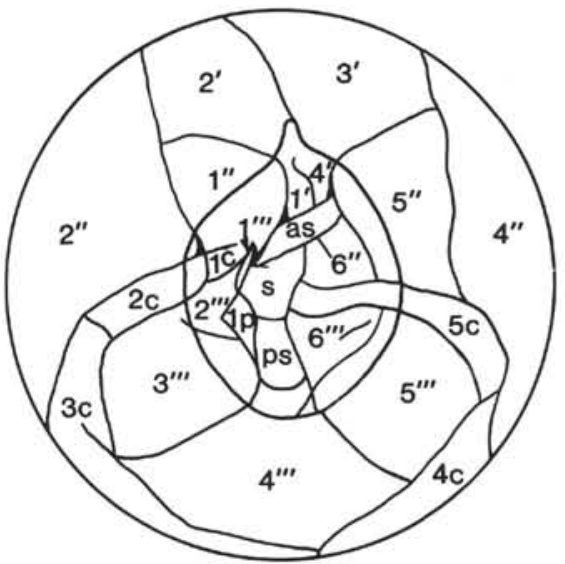

B

Figure 6. Paratabulation for Invertocysta tabulata n. gen., n. sp. (see Plate 3, Fig. 3). A. Dorsal surface.

B. Dorsal view of ventral surface.

1976 (contrast Fig. 6 with Eaton's text-figs. 18, 20). In T. delicata, the wall layers are appressed middorsally and the large ventral opening represents paraplate $1^{\prime \prime}$; in $I$. tabulata the wall layers are appressed midventrally, the large opening represents $3^{\prime \prime}$, and the paracingulum is displaced antapically.

Occurrence. Middle to upper Miocene in Hole 555, upper Miocene in Holes 552A, 554.

\section{Invertocysta lacrymosa $\mathrm{n} . \mathbf{s p}$. \\ (Plate 3, Figs. 4A,B, 5)}

Thalassiphora sp. cf. T. pelagica Habib, 1971, pl. 4, fig. 2.

"Thalassiphora delicata" Williams and Downie emend. Eaton, 1976, Harland, 1979, pl. 2, fig. 15.

Holotype. Plate 3, Figures 4 A,B, slide R 2712 BH (2), $19.0 \times$ 79.1, Sample $555-9-1,28-30 \mathrm{~cm}$.

Derivation of name. Latin, lacrimosus, tearful.

Diagnosis. Cyst cavate; ovoidal endocyst connected at apical boss to lip of bowl-shaped pericyst; periphragm and endophragm appressed midventrally; periphragm turned inward on dorsal side around opening representing 3 "; wall surfaces smooth to shagreenate with poorly to moderately developed parasutural ridges; paratabulation gonyaulacacean, exact formula undetermined; archeopyle precingular, type $\mathrm{P}, 3^{\prime \prime}$ only; dimensions of holotype, pericyst length $79 \mu \mathrm{m}$, pericyst width $85 \mu \mathrm{m}$, endocyst length $52 \mu \mathrm{m}$, endocyst width $44 \mu \mathrm{m}$.

Description. Cyst cavate; endocyst ovoidal to ellipsoidal with apical boss connecting endocyst to inner lip of pericyst; pericyst bowl-shaped with inward-turning lip at opening of bowl on dorsal side; periphragm and endophragm appressed midventrally; opening on dorsal side variable in size, shape, and position, ranging from a small opening on the dorsal epicyst to an opening of approximately the same size and shape as the endocyst to an opening that is considerably larger and broader than the endocyst; wall surfaces smooth to shagreenate with faint to moderately well-developed parasutural ridges; paracingulum displaced antapically on dorsal side, outline of paracingulum is in the shape of a hemicircle with the flat side centered across the ventral side; paratabulation gonyaulacacean, exact formula undetermined but presumably similar to that of $I$. tabulata, paraplates analogous to $3^{\prime \prime \prime}, 4^{\prime \prime}, 5^{\prime \prime \prime}$ and $1^{\prime \prime \prime}$ on $I$. tabulata are clearly visible on some specimens of $I$. lacrymosa; archeopyle precingular, type P, $3^{\prime \prime}$ only on endocyst, large opening corresponding to $3^{\prime \prime}$ on pericyst.

Dimensions. Pericyst length, average $76 \mu \mathrm{m}$, range $60-92 \mu \mathrm{m}$; pericyst width, average $77 \mu \mathrm{m}$, range $62-90 \mu \mathrm{m}$; endocyst length, average $44 \mu \mathrm{m}$, range 33-60 $\mu \mathrm{m}$; endocyst width, average $36 \mu \mathrm{m}$, range 29-46 $\mu \mathrm{m}$; dorsal opening length, average $58 \mu \mathrm{m}$, range $13-90 \mu \mathrm{m}$; dorsal opening width, average $56 \mu \mathrm{m}$, range $23-77 \mu \mathrm{m} ; 31$ specimens measured.

Remarks. This form shows a wide range of variation in size, shape, degree of definition of paratabulation, and size, shape, and position of the dorsal opening. As a rough trend, the middle Miocene specimens have smaller openings than late Miocene specimens. The specimens illustrated here are typical of the Rockall material. The specimens illustrated by Habib (1971) and Harland (1979) are end members in the limits of variation.
I. lacrymosa differs from I. tabulata in possessing a bowl-shaped, as opposed to disc-shaped, pericyst, in having less definition of paratabulation and in having a less "droopy" paracingulum. It differs from Thalassiphora delicata Williams and Downie, 1966, as emended by Eaton, 1976, in that the wall layers of $I$. lacrymosa are appressed midventrally and the large dorsal opening represents $3^{\prime \prime}$. In $T$. delicata, the wall layers are appressed middorsally and the large ventral opening represents $1^{\prime \prime}$. I. lacrymosa is distinguished from Amiculosphaera umbracula Harland, 1979, by the appression of periphragm and endophragm in the hypocyst of the latter.

Occurrence. Upper part of middle Miocene to upper Miocene in Hole 555, upper Miocene in Holes 552A and 554.

\section{Genus LABYRINTHODINIUM Piasecki, 1980 \\ Labyrinthodinium truncatum Piasecki, 1980 \\ (Plate 1, Fig. 9)}

Genus LINGULODINIUM Wall, 1967, emend. Wall and Dale, 1973

Lingulodinium machaerophorum (Deflandre and Cookson, 1955) Wall, 1967

(Plate 2, Fig. 2)

Remarks. Specimens of $L$. machaerophorum were encountered with 3P, 5P, and epitractal archeopyles. Those with epitractal archeopyles, as shown in Plate 2, Figure 2, are by far the most common.

Genus MELITASPHAERIDIUM Harland and Hill, 1979 Melitasphaeridium choanophorum (Deflandre and Cookson, 1955) Harland and Hill, 1979

(Plate 2, Fig. 8)

\section{Genus NEMATOSPHAEROPSIS Deflandre and Cookson, 1955 \\ Nematosphaeropsis labyrinthea (Ostenfeld, 1903) Reid, 1974} (Plate 2, Figs. 7A,B)

\section{“Nematosphaeropsis" aquaeducta Piasecki, 1980} (Plate 5, Fig. 1)

Remarks. In their comparison of the genera Cannosphaeropsis and Nematosphaeropsis, Stover and Evitt $(1978$, p. 143) stated that Cannosphaeropsis differs from Nematosphaeropsis in having single parasutural trabeculae between gonal positions. In Nematosphaeropsis, ectophragmal trabeculae represent extensions of the triradiate tips of the gonal processes so that at least two trabeculae connect adjacent processes." Other workers (e.g., Williams and Downie, 1966; May, 1980) have come to different conclusions about the two genera. Pending resolutions of these differences, "N." aquaeducta, which has single trabeculae between gonal positions, is considered a problematical species in "Nematosphaeropsis." 
Genus OPERCULODINIUM Wall, 1967

Operculodinium centrocarpum (Deflandre and Cookson, 1955)

Wall, 1967

(Plate 5, Fig. 2)

Remarks. This species is highly variable in size $(60-135 \mu \mathrm{m}$ including processes) and in degree of development of the processes. A typical specimen is shown in Plate 5, Figure 2.

\section{Operculodinium sp. of Piasecki, 1980}

(Plate 5, Fig. 3)

Operculodinium sp. Piasecki, 1980 , p. 70 , pl. 3, fig. 6 .

(?) ?Pyxidiella cf. scrobiculata (Deflandre and Cookson) Cookson and Eisenack, 1958, Harland, 1979, pl. 3, figs. 10,11.

Remarks. As stated by Piasecki (1980), this species is small, ovoid, and covered with short massive processes. The archeopyle is precingular, $3^{\prime \prime}$, only. Processes may be cylindrical to truncated conical and may be interconnected at the bases to varying degrees. A typical specimen is shown in Plate 5, Figure 3. Harland's specimen is somewhat atypical in having poorly delimited processes.

\section{Operculodinium sp. of Jan du Chêne, 1977}

(Plate 2, Figs. 3A,B)

Operculodinium sp. Jan du Chêne, 1977, p. 106, pl. 1, figs. 7,8.

Remarks. As noted by Jan du Chêne (1977), this species is subspherical to ovoid, has a simple precingular archeopyle and has short hollow spines, which are truncated and open at the ends.

Genus PALAEOCYSTODINIUM Alberti, 1961

Palaeocystodinium golzowense Alberti, 1961 sensu lato

(Plate 2, Figs. 1,6)

Remarks. Several of Piasecki's (1980, p. 70-71) comments are applicable here. The size is variable, and specimens are often shorter than Alberti's holotype; horns may be faintly granular.

\section{Genus PENTADINIUM Gerlach, 1961 \\ Pentadinium laticinctum Gerlach, 1961 (Plate 2, Fig. 4)}

Remarks. As noted by Benedek et al. (1982) and Edwards (1982), there is no consistent criterion for separating Pentadinium laticinctum and $P$. taeniagerum; the latter is restricted to its holotype. The Rockall specimens are faintly granular and some show pericoel development in the apical region.

\section{Genus SPINIFERITES Mantell, 1850}

Spiniferites mirabilis (Rossignol, 1963) Sarjeant, 1970

(Plate 2, Fig. 5)

Remarks. In the Rockall material, this species ranges in length from 60 to $120 \mu \mathrm{m}$. A typical specimen is shown in Plate 2, Figure 5 .

Spiniferites spp.

(Plate 2, Figs. 9,10,11)

Remarks. Numerous specimens of Spiniferites spp, were found in the Rockall material. Because of their variability and often poor preservation, no attempt was made to identify them at the species level. Three typical forms are shown in Plate 2, Figures 9,10,11.

\section{Spiniferites-group sp. I}

(Plate 5, Fig. 9)

Remarks. This small equant form with high septa is common in several samples in the Rockall Plateau material. It lacks typical Spiniferites-type processes and appears intermediate between Spiniferites and Impagidinium.

\section{Spiniferites-group sp. II}

$$
\text { (Plate 2, Fig. 12) }
$$

Remarks. This form is thin-walled and appears very faint. The truncated-tipped processes are atypical in Spiniferites.
Genus SYSTEMATOPHORA Klement, 1960

\author{
Systematophora placacantha (Deflandre and Cookson, 1955) Davey \\ et al., 1969
}

(Plate 3, Fig. 1)

\section{Genus TECTATODINIUM Wall, 1967}

Tectatodinium pellitum Wall, 1967

(Plate 3, Fig. 2) wall.

Remarks. This species shows varying thickness $(1-4 \mu \mathrm{m})$ of the Tectatodinium simplex (Harland, 1979) n. comb.

(Plate 5, Figs. 8A,B, 10A,B)

?Pyxidiella sp. nov. Harland, 1978, pl. 3, figs. 3,4.

?Pyxidiella simplex Harland, 1979, p. 537-538, pl. 3, fig. 12; not pl. 3, figs. $13,14,15$.

(?) Tectatodinium psilatum Wall and Dale, 1973, Piasecki, 1980, pl. 4, figs. 2,3 .

Remarks. As described by Harland, this species is ovoid (in dorsal-ventral view) and has a coarse positive ornament. The archeopyle, however, is precingular, not intercalary. The outline in lateral view is distinctive, showing a prominent dorso-antapical bulge and a protruding paracingular area (Plate 5, Figs. 10A,B), as does Harland's holotype. The species resembles Tectatodinium psilatum Wall and Dale, 1973 , from which it differs in lateral profile and in the generally coarser ornament. The specimen figured by Piasecki as $T$. psilatum is most probably $T$. simplex n. comb.

Genus TUBERCULODINIUM Wall, 1967

Tuberculodinium vancampoae (Rossignol, 1962) Wall, 1967

(Plate 5, Fig. 11)

Genus Unknown

“Gen. et sp. indet.” of Piasecki, 1980

(Plate 5, Fig. 7)

Gen. et sp. indet. Piasecki, 1980, p. 71, pl. 3, fig. 3; pl. 6, figs. 5,6. Remarks. As noted by Piasecki, this small form has a precingular archeopyle and is covered with discontinuous crests, which probably reflect paratabulation.

\section{Gonyaulacacean cyst group (Plate 4, Figs. 5A,B, 7A,B,C, 8)}

Remarks. These forms are spherical with a precingular archeopyle, a "fuzzy" outline, and varying amounts of paratabulation expressed. More work, and more specimens, are required on this group.

$$
\begin{gathered}
\text { Incertae sedis sp. I } \\
\text { (Plate 3, Figs. 7A, B, 8) }
\end{gathered}
$$

Remarks. This form has a five-sided archeopyle, which is therefore presumably $3^{\prime \prime}$, and has six long blunt-tipped processes, which are triradiate in cross section. Eleven specimens were well-enough preserved to be measurable. For the cyst body, length averages $60 \mu \mathrm{m}$ (range 52-79 $\mu \mathrm{m}$ ), width averages $43 \mu \mathrm{m}$ (range 31-56 $\mu \mathrm{m}$ ). Processes range in length from 27 to $60 \mu \mathrm{m}$, with the average at $45 \mu \mathrm{m}$, but this may be too low because the processes often lie at an angle to the plane of the slide. The processes are consistently arranged: two on the epicyst, four on the hypocyst. On the epicyst, one process is on the dorsal surface, towards the right-lateral side; one is on the ventral surface, towards the left-lateral side. On the hypocyst, two processes are closely spaced and nearly symmetrical about the middorsal surface, and two processes are nearly symmetrical, more widely spaced about the ventral surface. A single, atypical specimen (Plate 3, Fig. 8) showed well-developed gonaulacacean paratabulation and prominent apical projection.

Incertae sedis sp. II

(Plate 3, Figs. 6A,B,C)

Remarks. This form resembles Impagidinium strialatum (Wall, 1967) Stover and Evitt, 1978, in size and in having weakly striate septa, but 
differs in having septa outlining the archeopyle. The paratabulation is incompletely known.

\section{Polykrikos? Bütschli, 1873}

(Plate 4, Fig. 4)

Remarks. Specimens such as illustrated in Plate 4, Figure 4 are common in some samples of the Rockall material. They are probably cysts of Polykrikos.

\section{Reworked Paleogene material}

(Plate 4, Fig. 6)

Remarks. Specimens of Apectodinium homomorphum (Deflandre and Cookson, 1955) Lentin and Williams, 1977; Wilsonidium tabulatum (Wilson, 1967) Lentin and Williams, 1976 (Plate 4, Fig. 6); and Wetzeliella spp. were occasionally found in the Rockall material. These specimens presumably have been reworked from the Paleogene.

\section{ACKNOWLEDGMENTS}

I would like to thank Jack Baldauf (USGS, Menlo Park), Sarah Pierce Damassa (consultant, Boston), and David Wall (Amoco, Denver) for their most helpful comments on earlier versions of this manuscript. Cynthia Crampsey (USGS, Reston) provided invaluable technical assistance on all aspects of this work.

\section{REFERENCES}

Agelopoulos, J., 1964. Hystrichostrogylon membraniphorum n.g. $\mathrm{n}$. sp. aus dem Heiligenhafener Kieselton (Eozän). Neues Jahrb. Geol. Paläontol., Monatsh., pp. 673-675.

Alberti, G., 1961. Zur Kenntnis mesozoischer und alttertiärer Dinoflagellaten und Hystrichosphaerideen von Nord- und Mitteldeutschland sowie einigen anderen Europäischen Gebieten. Palaeontographica, Abt. A. 116:1-58.

Benedek, P. N. v., Gocht, H., and Sarjeant, W. A. S., 1982. The dinoflagellate cyst genus Pentadinium Gerlach: a re-examination. Neues Jahrb. Geol. Paläontol., Abh., 162(3):265-285.

Bujak, J. P., and Davies, E. H., 1981. Neogene dinoflagellate cysts from the Hunt Dome Kopanoar M-13 well, Beaufort Sea, Canada. Bull. Can. Pet. Geol., 29:420-425.

Bujak, J. P., Downie, C., Eaton, G. L., and Williams, G. L., 1980. Taxonomy of some Eocene dinoflagellate cyst species from southern England. In Bujak, J. P., Downie, C., Eaton, G. L., and Williams, G. L., Dinoflagellate Cysts and Acritarchs from the Eocene of Southern England. Palaeontol. Assoc. Spec. Pap. Palaeontol., 24:26-36.

Bütschli, O., 1873. Einiges über Infusorien. Archiv für mikroskopische Anatomie, 9, 657-678, pl. 25-26.

Cookson, I. C., and Eisenack, A., 1958. Microplankton from Australian and New Guinea Upper Mesozoic sediments. Proc. R. Soc. Victoria, 70:19-79.

Costa, L. I., and Downie, C., 1979. Cenozoic dinocyst stratigraphy of Sites 403 to 406 (Rockall Plateau), IPOD, Leg 48. In Montadert, L., Roberts, D. G., et al., Init. Repts. DSDP, 48: Washington (U.S. Govt. Printing Office), 513-529.

Davey, R. J., Downie, C., Sarjeant, W. A. S., and Williams, G. L., 1969. Generic reallocations. In Davey, R. J., Downie, C., Sarjeant, W. A. S., and Williams, G. L., Appendix to "Studies on Mesozoic and Cainozoic Dinoflagellate Cysts," Bull. Brit. Mus. Nat. Hist. Geol., Suppl., 3:15-17.

Deflandre, G., 1935. Considérations biologiques sur les microorganisms d'origine planctonique coservés dans les silex de la craie. Bull. Biol. France, Belgique, 69:213-244.

Deflandre, G., and Cookson, I. C., 1955. Fossil microplankton from Australian Late Mesozoic and Tertiary sediments. Aust. J. Mar. Freshwater Res., 6:242-313.

Drugg, W. S., 1970, Some new genera, species, and combinations of phytoplankton from the Lower Tertiary of the Gulf Coast, U.S.A. Proc. North Am. Paleontol. Conv., pp. 809-843.

Eaton, G. L., 1976. Dinoflagellate cysts from the Bracklesham Beds (Eocene) of the Isle of Wight, Southern England. Bull. Brit. Mus. Nat. Hist. Geol. , 26:227-332.

Edwards, L. E., 1982. Biostratigraphically important species of Pentadinium Gerlach 1961 and a likely ancestor, Hafniasphaera good- manii n. sp., from the Eocene of the Atlantic and Gulf Coastal Plains. Palynology, 6:105-117.

Fritsch, F. E., 1935. The Structure and Reproduction of the Algae: London (Cambridge University Press), 1:1-791.

Gerlach, E., 1961. Mikrofossilien aus dem Oligozän und Miozän Nordwestdeutschlands, unter besonderer Berücksichtigung der Hystrichosphaeren und Dinoflagellaten. Neues Jahrb. Geol. Paläontol. Abh., 112:143-228.

Habib, D., 1971. Dinoflagellate stratigraphy across the Miocene-Pliocene boundary, Tabiano stratotype section. In Farinacci, A. (Ed.), Proc. 2nd Plankt. Conf.: Roma (Tecnoscienza), 1:591-598.

1972. Dinoflagellate stratigraphy Leg 11, Deep Sea Drilling Project. In Hollister, C. D., Ewing, J. I., et al., Init. Repts. DSDP, 11: Washington (U.S. Govt. Printing Office), 367-425.

Haeckel, E., 1894. Systematisch Phylogenie. Entwurf eines Natürlichen Systems der Organismen auf Grund ihre Stammengeschichte. Erster Theil: Systematische Phylogenie der Protisten und Pflanzen: Berlin (Georg Reimer), pp. 1-400.

Harland, R., 1978. Quaternary and Neogene dinoflagellate cysts. In Thusu, B. (Ed.), Distribution of Biostratigraphically Diagnostic Dinoflagellate Cysts and Miospores from the Northwest European Continental Shelf and Adjacent Areas. Continental Shelf Institute Publications (Trondheim) Pub. 100, pp. 7-18.

1979. Dinoflagellate biostratigraphy of Neogene and Quaternary sediments at Holes 400/400A in the Bay of Biscay (Deep Sea Drilling Project Leg 48). In Montadert, L., Roberts, D. G., et al., Init. Repts. DSDP, 48: Washington (U.S. Govt. Printing Office), 531-545.

Harland, R., and Hill, J., 1979. A reappraisal of the Cainozoic dinoflagellate cyst "Hystrichosphaeridium" choanophorum Deflandre et Cookson, 1955. Rev. Palaeobot. Palynol., 28:37-45.

Jan du Chêne, R., 1977. Étude palynologique du Miocene superieur Andalou (Espagne). Rev. Esp. Micropaleontol., 9:97-114.

Klement, K. W., 1960. Dinoflagellaten und Hystrichosphaerideen aus dem unteren und mittleren Malm Südwestdeutschland. Palaeontographica, Abt. A, 114:1-104.

Klumpp, B., 1953. Beitrag zur Kenntnis der Mikrofossilien des mittleren und oberen Eozän. Palaeontographica, Abt. A, 103: 377-406.

Lentin, J. K., and Williams, G. L., 1976. A monograph of fossil peridinioid dinoflagellate cysts. Bedford Inst. Oceanography Rept. (BI-R-75-16), pp. 1-237.

1977. Fossil dinoflagellates: Index to genera and species. Bedford Instit. Oceanography Rept. (BI-R-77-8), pp. 1-209.

Maier, D., 1959. Planktonuntersuchungen in tertiären und quartären marinen Sedimenten. Ein Beitrag zur Systematik, Stratigraphie und Okologie der Coccolithophorideen, Dinoflagellaten und Hystrichosphaerideen vom Oligozän bis zum Pleistozän. Neues Jahrb. Geol. Paläontol., Abh., 107:278-340.

Mantell, G. A., 1850. A Pictorial Atlas of Fossil Remains Consisting of Coloured Illustrations Selected from Parkinson's "Organic Remains of a Former World," and Artis's "Antediluvian Phytology": London (Henry G. Bohn), pp. 1-207.

Manum, S., 1976. Dinocysts in Tertiary Norwegian-Greenland Sea sediments (Deep Sea Drilling Project Leg 38), with observations on palynomorphs and palynodebris in relation to environment. In Talwani, M., Udintsev, G., et al., Init. Repts. DSDP, 38: Washington (U.S. Govt. Printing Office), 897-919.

May, F. E., 1980. Dinoflagellate cysts of the Gymnodiniaceae, Peridiniaceae, and Gonyaulacaceae from the Upper Cretaceous Monmouth Group, Atlantic Highlands, New Jersey. Palaeontographica, Abt. B, 172:10-116.

Morgenroth, P., 1968. Zur Kenntnis der Dinoflagellaten und Hystrichosphaeridien des Danien. Geol. Jahrb., 86:533-578.

Ostenfeld, C. H., 1903. Phytoplankton from the Sea Around the Faeroes; Botany of the Faeroes. Copenhagen (Det Nordiske Forlag), pp. 558-612.

Pascher, A., 1914. Über Flagellaten and Algen. Ber. Dtsch. Bot. Ges., 32:136-160.

Piasecki, S., 1980. Dinoflagellate cyst stratigraphy of the Miocene Hodde and Gram Formations, Denmark. Geol. Soc. Denmark Bull., 29:53-76.

Reid, P. C., 1974. Gonyaulacacean dinoflagellate cysts from the British Isles. Nova Hedwigia, 25:579-637. 
Rossignol, M., 1962. Analyse pollinique de sédiments marins Quaternaires en Israël. II. Sédiments Pléistocènes. Pollen Spores, 4: 121-148.

, 1963. Aperçus sur le développement des hystrichosphères. Bull. Mus. Hist. Nat., Paris, sér. 2, 35:207-212.

Sarjeant, W. A. S., 1970. The genus Spiniferites Mantell, 1850 (Dinophyceae). Grana, 10:74-78.

Shimakura, M., Nishida, S., and Matsuoka, K., 1971. Some plant microfossils from Yamato-tai, Sea of Japan, Nara University of Education, Natural Science Bull., 20:63-70.

Stover, L. E., 1977. Oligocene and early Miocene dinoflagellates from Atlantic Corehole 5/5B, Blake Plateau. Am. Assoc. Strat. Palynol., Contrib. Ser., 5A:66-89.

Stover, L. E., and Evitt, W. R., 1978. Analyses of pre-Pleistocene organic-walled dinoflagellates. Stanford Univ. Publ., Geol. Sci., 15: 1-300.

Wall, D., 1967. Fossil microplankton in deep-sea cores from the Caribbean Sea. Palaeontology, 10:95-123.

Wall, D., and Dale, B. In Wall, D., Dale, B., and Harada, K., 1973. Descriptions of new fossil dinoflagellates from the Late Quaternary of the Black Sea. Micropaleontology, 19:18-31.
Wetzel, O., 1933. Die in organischer Substanz erhaltenen Mikrofossilien des baltischen Kreide-Feuersteins mit einem sediment-petrographischen und stratigraphischen Anhang. Palaeontographica, Abt. A, 78:1-110.

Williams, G. L., 1975. Dinoflagellate and spore stratigraphy of the Mesozoic-Cenozoic, offshore eastern Canada. Geol. Surv. Canada, Pap., 74-30, 2:107-161.

, 1977. Dinocysts. In Ramsay, A. T. S. (Ed.), Oceanic Micropalaeontology (Vol. 2): London (Academic Press), pp. 1231-1325.

Williams, G. L., and Brideaux, W. W., 1975. Palynologic analyses of Upper Mesozoic and Cenozoic rocks of the Grand Banks, Atlantic Continental Margin. Geol. Surv. Canada Bull., 236:1-163.

Williams, G. L., and Downie, C., 1966. Further dinoflagellate cysts from the London Clay. In Davey, R. J., Downie, C., Sarjeant, W. A. S., and Williams, G. L., Studies on Mesozoic and Cainozoic Dinoflagellate Cysts. Bull. Brit. Mus. Nat. Hist. Geol., Suppl., 3: 215-235.

Wilson, G. J., 1967. Some species of Wetzeliella Eisenack (Dinophyceae) from New Zealand Eocene and Paleocene strata. N.Z. J. Bot., 5: 469-497.

Date of Acceptance: July 8, 1983 

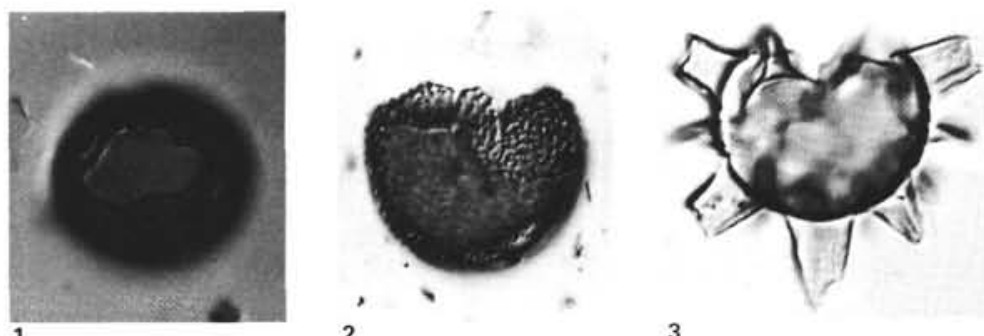

3

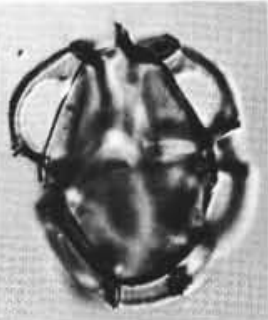

5B

5C
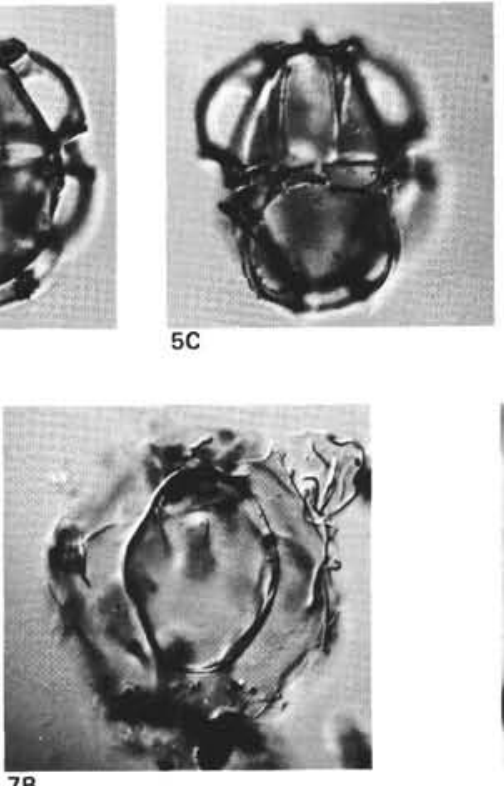

$7 B$
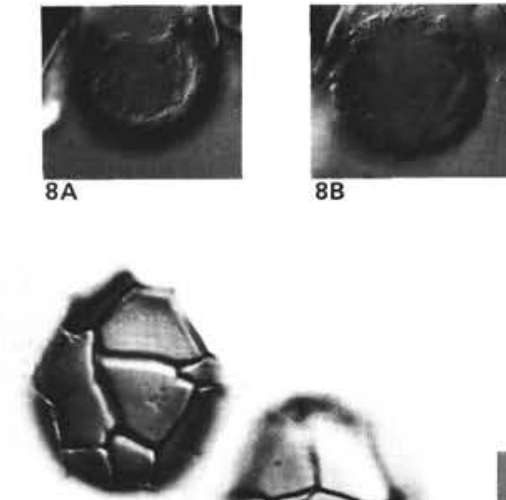

$11 \mathrm{~A}$

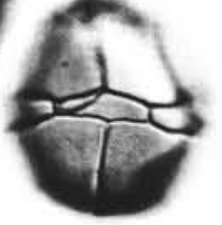

11B

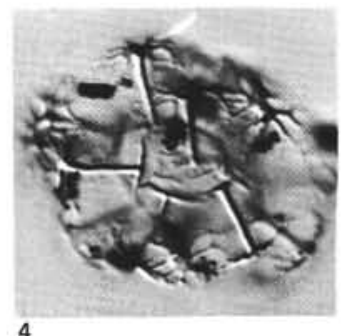

4
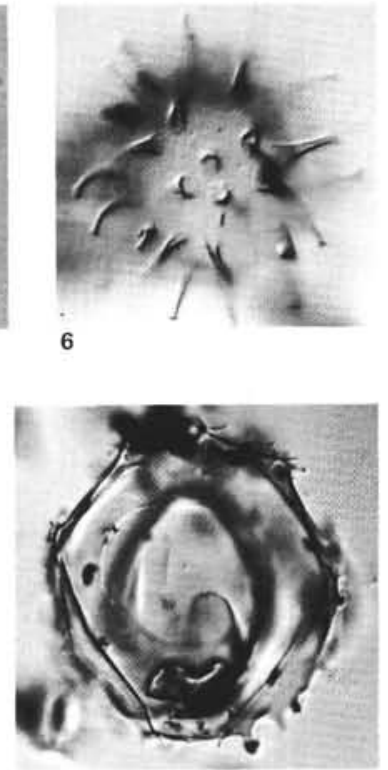

$7 C$
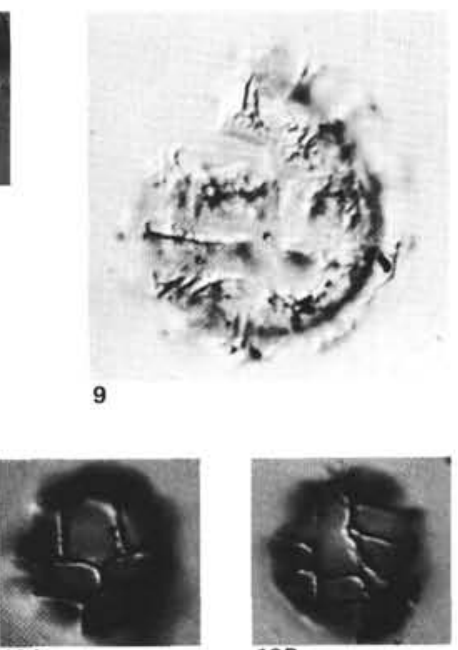

12B

Plate 1. 1. Batiacasphaera sphaerica Stover, 1977. Sample 555-21-2, 60-62 cm, R $2712 \mathrm{AW}(1), 33.8 \times 101.4$, max. diam. $33 \mu \mathrm{m}$, apical view. 2 . Batiacasphaera sp. I. Sample 553A-7-3, 130-134 cm, R 2713 U (2), $36.8 \times 97.8$, length $38 \mu \mathrm{m}$, ?dorsal view of dorsal surface. 3. Hystrichokolpoma sp. Sample 555-14-1, 20-22 cm, R 2712 BD (2), $21.0 \times 79.2$, length $47 \mu \mathrm{m}$, optical section (ventral view). 4. ?Cannosphaeropsis sp. b of Shimakura et al., 1971. Sample 555-21-2, 60-62 cm, R 2712 AW (1), $35.2 \times 77.4$, max. diam. $54 \mu \mathrm{m}$, orientation unknown. 5. Cannosphaeropsis? sp. Sample 555-8-6, 96-98 cm, R 2712 BI (2), $36.5 \times 92.4$, length $80 \mu \mathrm{m}$, ventral views, (A) ventral surface, (B) optical section, (C) dorsal surface. 6. Dapsilidinium pseudocolligerum (Stover, 1977) Bujak et al., 1980. Sample 555-22-1, 107-109 cm, R 2712 AV (1), $36.7 \times$ 80.0, diam. $57 \mu \mathrm{m}$, antapical view of antapical surface. 7. Hystrichostrogylon sp. Sample 555-21-2, 60-62 cm, R $2712 \mathrm{AW}(1), 29.7 \times 76.1$, length $85 \mu \mathrm{m}$, dorsal views, (A) dorsal surface, (B) optical section, (C) ventral surface. 8. Batiacasphaera sp. II. Sample 555-19-2, 45-47 cm, R 2712 AY (2), $23.9 \times 79.8$, diam. $40 \mu \mathrm{m}$, orientation uncertain. 9. Labyrinthodinium truncatum Piasecki, 1980. Sample 555-19-2, 45-47 cm, $\mathrm{R}$ 2712 AY (2), $32.6 \times 80.1$, length $54 \mu \mathrm{m}$, right-lateral view. 10. Hystrichosphaeropsis obscura Habib, 1972. Sample 555-22-1, 107-109 cm, R 2712 AV (1), $36.9 \times 96.7$, length $135 \mu \mathrm{m}$, left-lateral view. 11. Impagidinium patulum (Wall, 1967) Stover and Evitt, 1978. Sample 552A-28-3, 137-141 cm, R 2869 J (1) $29.4 \times 91.5$, length $70 \mu \mathrm{m}$, ventral views, (A) ventral surface, (B) dorsal surface. 12. Impagidinium sp. Sample 554-6-6, $30-32 \mathrm{~cm}, \mathrm{R} 2870 \mathrm{C}$ (1), $29.0 \times 78.9$, length $29 \mu \mathrm{m}$, ventral views, (A) dorsal surface (B) ventral surface. 

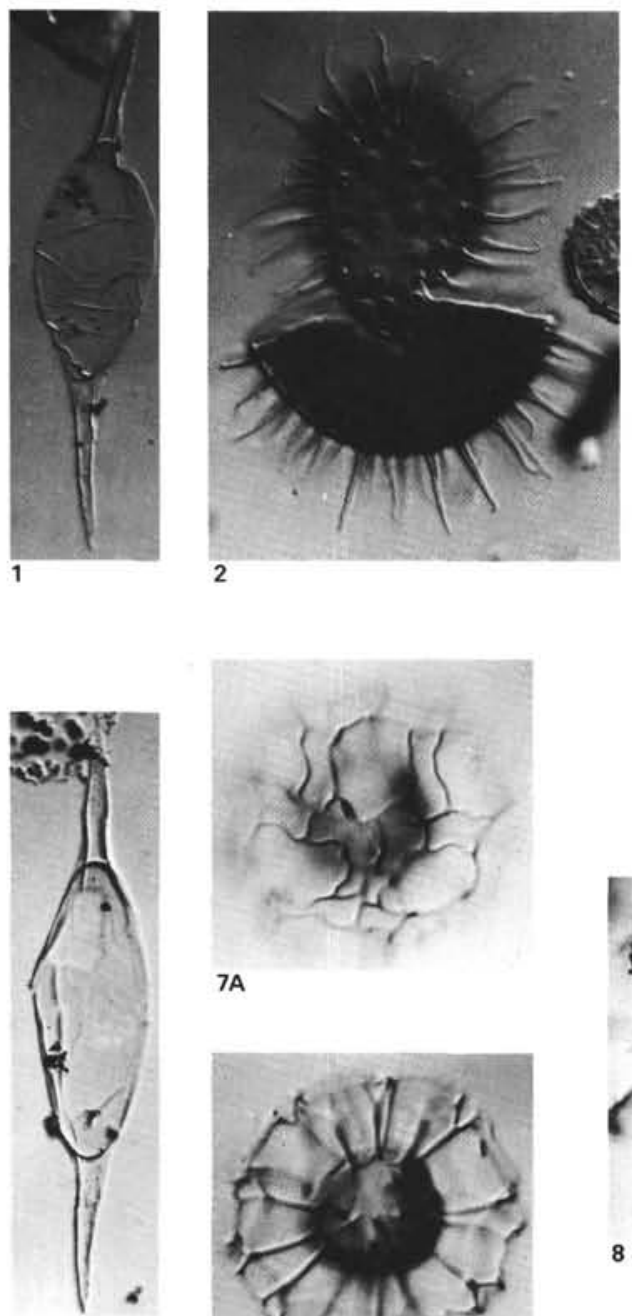

$7 \mathrm{~A}$
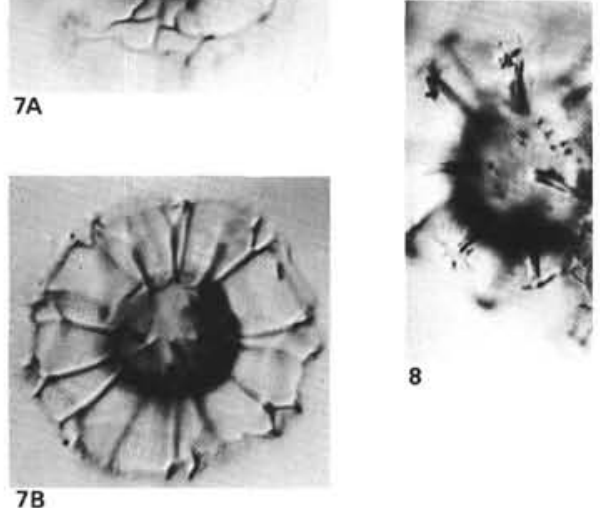

8

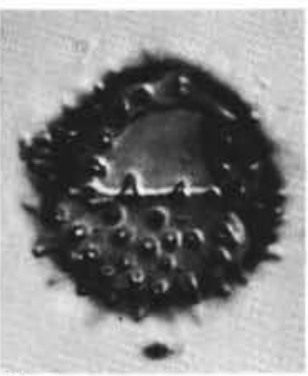

$3 \mathrm{~A}$

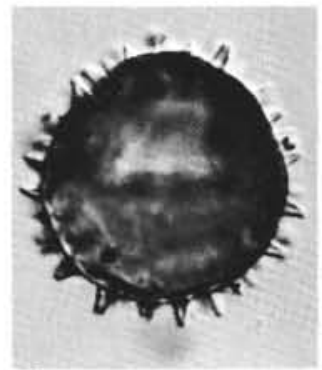

3B

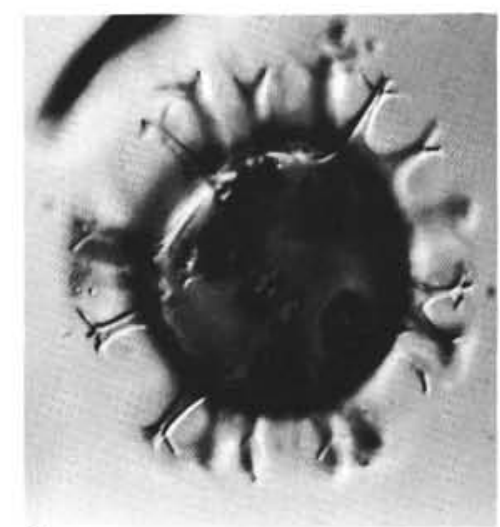

9

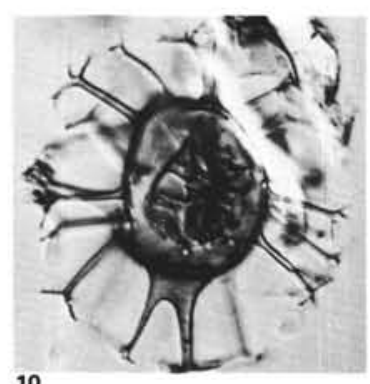

10

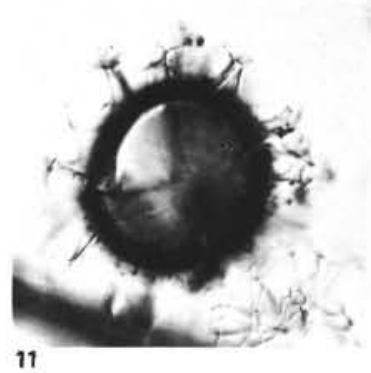

11

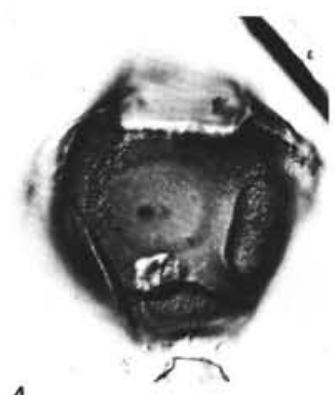

4

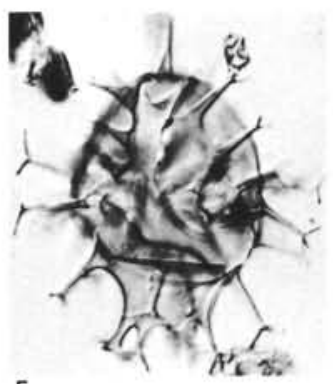

5

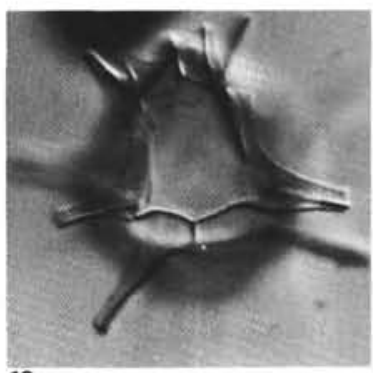

12

Plate 2. 1. Palaeocystodinium golzowense Alberti, 1961. Sample 555-19-2, $45-47 \mathrm{~cm}, \mathrm{R} 2712 \mathrm{AY}(2), 30.0 \times 87.1$, length $134 \mu \mathrm{m}$, dorsal view of dorsal surface. 2. Lingulodinium machaerophorum (Deflandre and Cookson, 1955) Wall, 1967. Sample 555-19-2, 45-47 cm, R 2712 AY (2), $21.8 \times 109.1$, length $127 \mu \mathrm{m}$, ventral view of ventral surface showing attached epitractal archeopyle. 3. Operculodinium sp. of Jan du Chêne, 1977. Sample 555-15-1, 50-52 cm, R 2712 BC (2), $26.0 \times 104.5$, length $50 \mu \mathrm{m}$, dorsal views, (A) dorsal surface, (B) optical section. 4. Pentadinium laticinctum Gerlach, 1961. Sample 555-16-5, 50-52 cm, R 2712 BB (2), $27.8 \times 101.9$, length $73 \mu \mathrm{m}$, dorsal view of dorsal surface. 5 . Spiniferites mirabilis (Rossignol, 1963) Sarjeant, 1970. Sample 555-5-6, 45-47 cm, R 2712 BL (2), $25.2 \times 100.8$, length $95 \mu \mathrm{m}$, dorsal view of dorsal surface. 6. Palaeocystodinium golzowense Alberti, 1961 . Sample $555-15-1,50-52 \mathrm{~cm}, \mathrm{R} 2712 \mathrm{BC}(2), 27.0 \times 74.6$, length $156 \mu \mathrm{m}$, ventral view at mid-focus. 7. Nematosphaeropsis labyrinthea (Ostenfeld, 1903) Reid, 1974. Sample 555-22-1, $107-109 \mathrm{~cm}, \mathrm{R} 2712 \mathrm{AV}(1), 37.0 \times$ 99.4, length $53 \mu \mathrm{m}$, dorsal views, (A) high focus showing trabeculae, (B) dorsal surface. 8. Melitasphaeridium choanophorum (Deflandre and Cookson, 1955) Harland and Hill,1979. Sample 555-9-1, 28-30 cm, R 2712 BH (2), $37.0 \times 106.0$, length from tip to tip of processes that are in focus $46 \mu \mathrm{m}$, detail of process tips, orientation unknown. 9. Spiniferites sp. Sample 555-19-2, $45-47 \mathrm{~cm}$, R $2712 \mathrm{AY}(2), 35.2 \times 109.4$, length $73 \mu \mathrm{m}$, dorsal view of optical section. 10. Spiniferites sp. Sample 555-5-6, 45-47 cm, R $2712 \mathrm{BL}(2), 33.4 \times 89.2$, length $92 \mu \mathrm{m}$, right-lateral view. 11. Spiniferites sp. Sample 555-16-5, 50-52 cm, R 2712 BB (2), $32.9 \times 100.8$, length $85 \mu \mathrm{m}$, right-lateral view. 12. Spiniferites-group sp. II. Sample 555-20-1, 50-52 cm, R 2712 AX (2), $21.2 \times 77.7$, length $54 \mu \mathrm{m}$, ventral view of dorsal surface. 


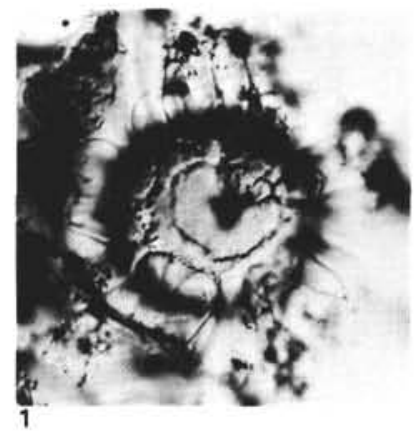

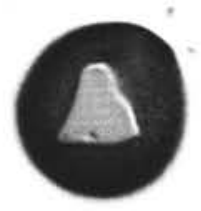

2

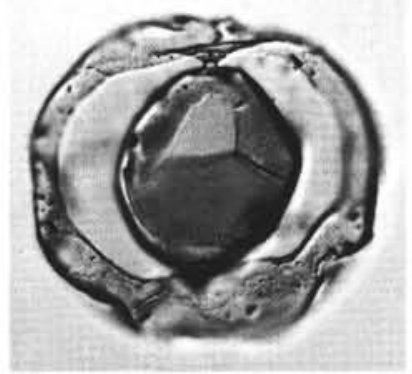

4B

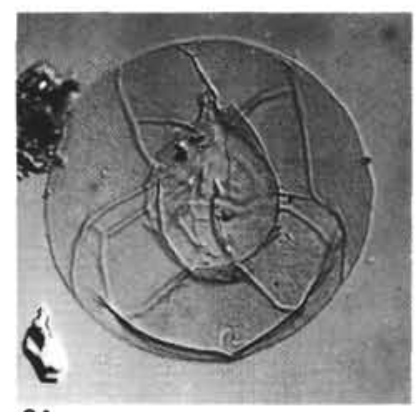

$3 A$

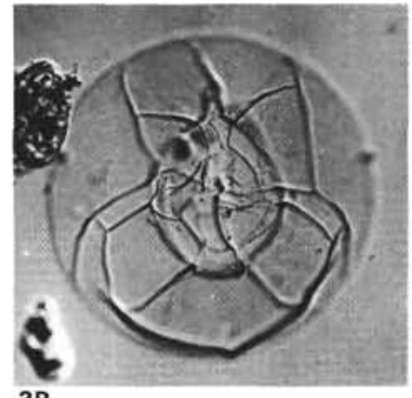

3B

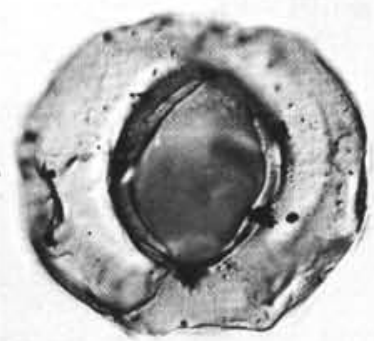

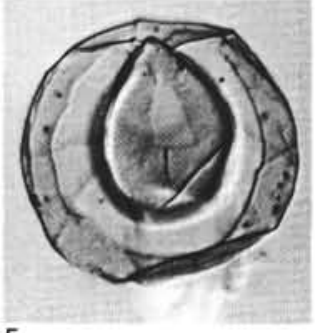

5

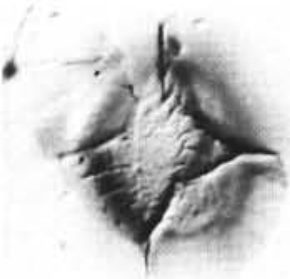

6A

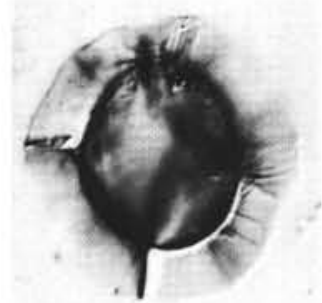

6B

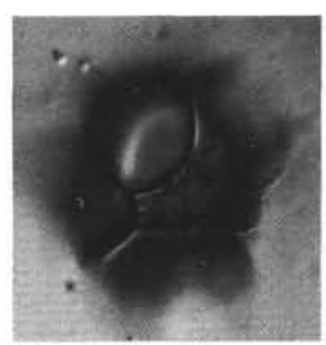

6C

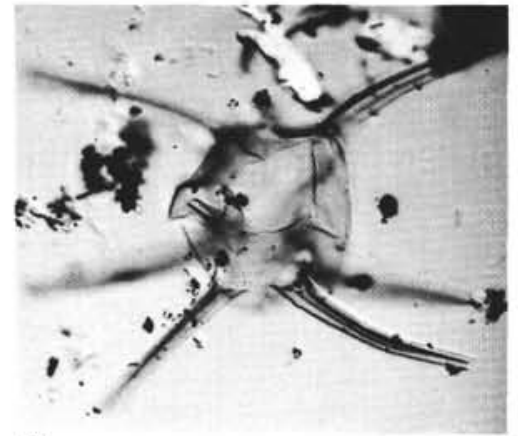

$7 A$

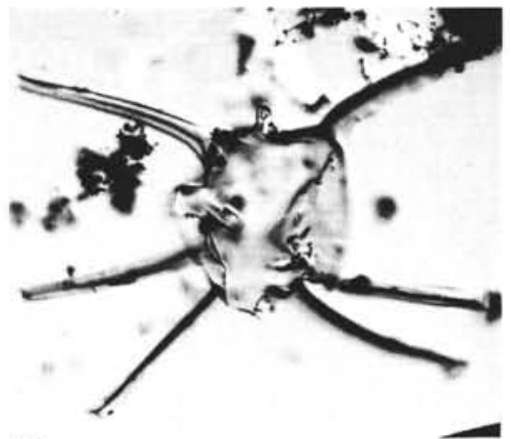

7B

Plate 3. 1. Systematophora placacantha (Deflandre and Cookson, 1955) Davey et al., 1969. Sample 555-24-3, 70-72 cm, R 2712 AU (1), 36.4 $\times$ 96.1, length $67 \mu \mathrm{m}$, apical view of antapical surface. 2. Tectatodinium pellitum Wall, 1967. Sample 552A-26-2, 120-124 cm, R 2869 L (1), 23.6 $\times 98.6$, diameter $28 \mu \mathrm{m}$, dorsal view of dorsal surface. 3. Invertocysta tabulata $\mathrm{n}$. gen., $\mathrm{n}$. sp. Holotype. Sample 555-15-1, 50-52 cm, R 2712 BC (2), $35.5 \times 103.3$, length $90 \mu \mathrm{m}$, dorsal views, (A) dorsal surface, (B) ventral surface. 4. Invertocysta lacrymosa n. gen., n. sp. Holotype. Sample 555-9-1, 28-30 cm, R 2712 BH (2), $19.0 \times 79.1$, length $80 \mu \mathrm{m}$, ventral views, (A) ventral surface, (B) dorsal surface. 5. Invertocysta lacrymosa n. gen., n. sp. Paratype. Sample 555-5-6, 45-47 cm, R 2712 BL (2), $25.0 \times 91.1$, length $67 \mu \mathrm{m}$, ventral view of dorsal surface. 6 . Incertae sedis sp. II. Sample 552A-29-2, 124-128 cm, R. 2869 I (1), $29.6 \times 93.1$, length $47 \mu \mathrm{m}$, ventral? views through specimen. 7. Incertae sedis sp. I. Sample 555-10-5, 70-72 cm, R 2712 BG (1), $29.0 \times 87.8$, width from tips of spines $125 \mu \mathrm{m}$, dorsal views, (A) dorsal surface, (B) ventral surface. 8. Incertae sedis sp. I. Sample 555-15-1, 50-52 cm, R 2712 BC (2), $29.1 \times 99.4$, length excluding spines $79 \mu \mathrm{m}$, ventral view of ventral surface. 

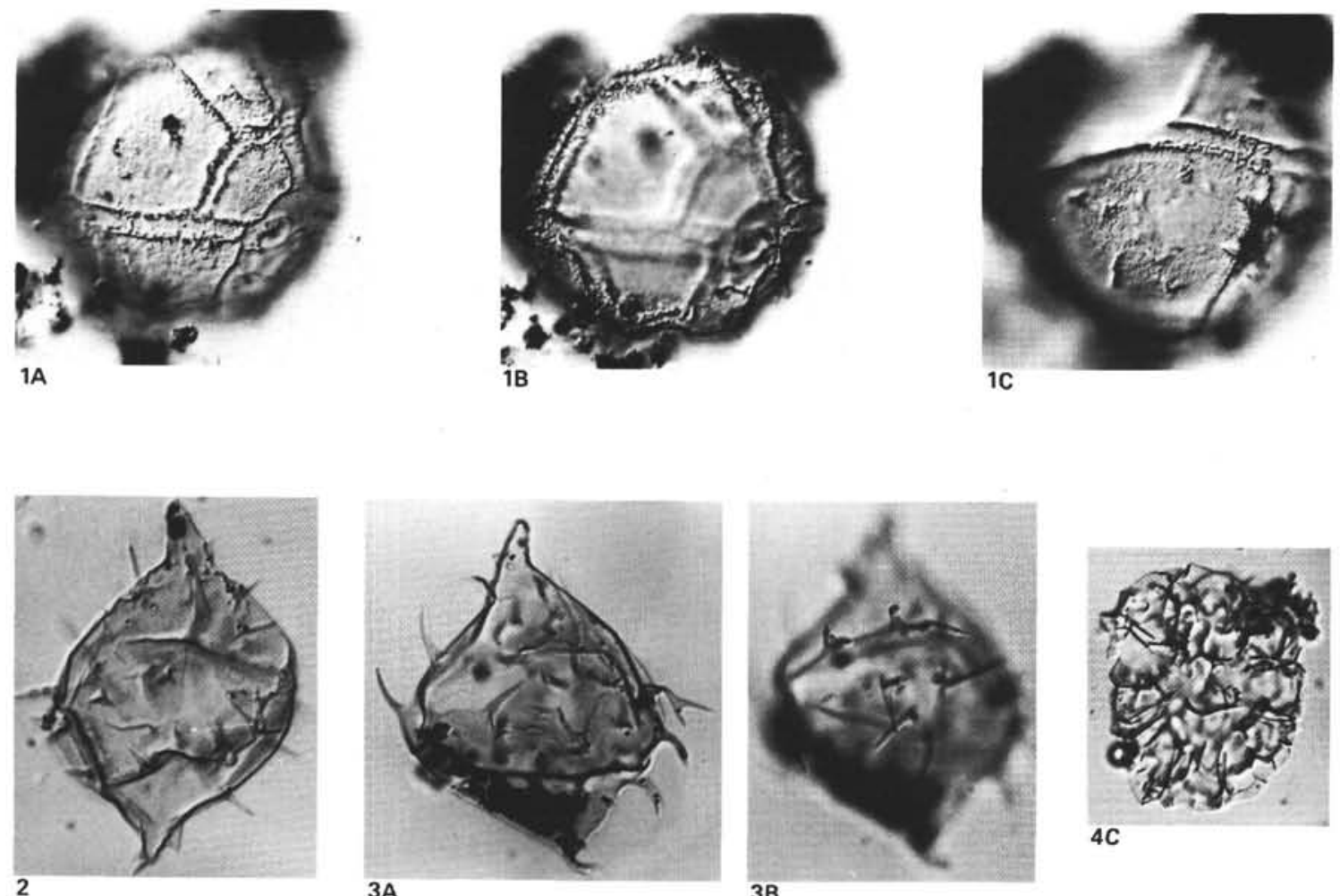

$4 C$

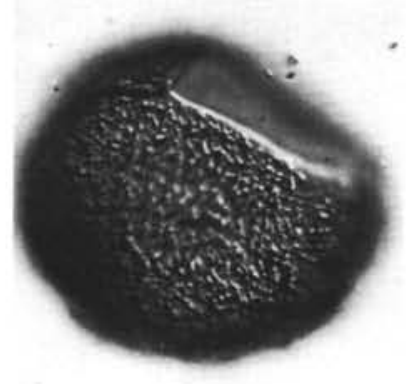

$5 A$
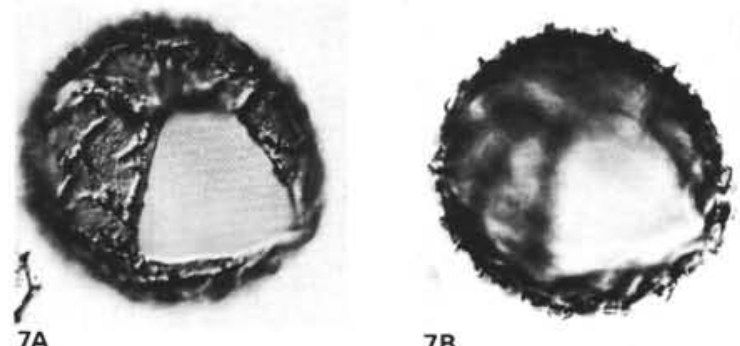

$7 \mathrm{~B}$

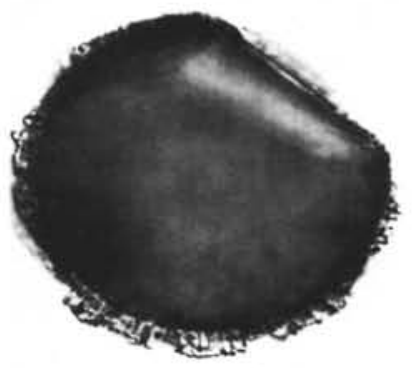

5B

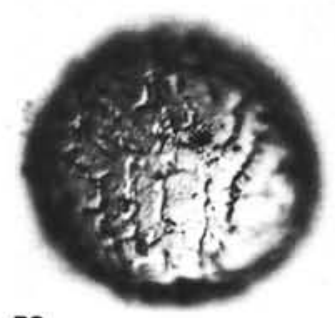

$7 C$

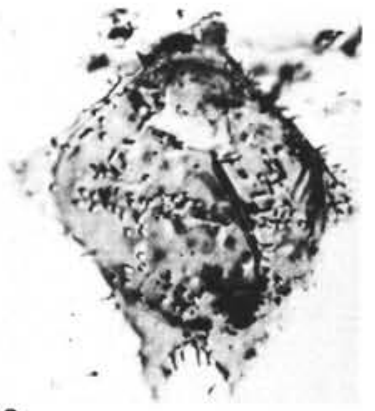

$6 C$

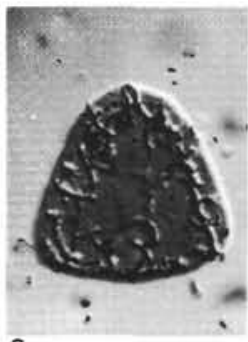

Plate 4. 1. Danea? sp. Sample 555-21-2, 60-62 cm, R 2712 AW (1), $30.1 \times 86.8$, length $96 \mu \mathrm{m}$, ventral views, (A) ventral surface, high focus, (B) ventral surface, lower focus, (C) dorsal surface. 2. Fibrocysta? fusiforma $\mathrm{n}$. sp. Holotype. Sample 555-7-6, $44-48 \mathrm{~cm}, \mathrm{R} 2712 \mathrm{BJ}(2), 33.7 \times$ 77.4 , length $75 \mu \mathrm{m}$, ventral view of dorsal surface. 3. Fibrocysta? fusiforma $\mathrm{n}$. sp. Paratype. Sample 555-9-1, 28-30 cm, R $2712 \mathrm{BH}(2), 30.9 \times$ 103.5, length $71 \mu \mathrm{m}$, right lateral views, (A) upper surface, (B) lower surface. 4. Polykrikos? Sample 555-15-1, 50-52 cm, R 2712 BC (2), 18.7 $\times 87.6$, length $64 \mu \mathrm{m}$. 5. Gonyaulacacean cyst group. Sample 555-16-5, 50-52 cm, R $2712 \mathrm{BB}(2), 30.5 \times 108.3$, max. diam, $92 \mu \mathrm{m}$, dorsal views, (A) dorsal surface, (B) optical section. 6. Wilsonidium tabultaum (Wilson, 1967) Lentin and Williams, 1976. Sample 555-3-7, 40-42 cm, R 2712 BN (1), $21.4 \times 74.2$, length $102 \mu \mathrm{m}$, dorsal view of dorsal surface, reworked. 7. Gonyaulacacean cyst group. Sample 555-14-1, 20-22 $\mathrm{cm}, \mathrm{R} 2712 \mathrm{BD}(2), 33.3 \times 78.7$, max. diam. $81 \mu \mathrm{m}$, dorsal views, (A) dorsal surface, (B) optical section, (C) ventral surface. 8. Gonyaulacacean cyst group. Sample 555-14-1, 20-22 cm, R 2712 BD (2), $16.9 \times 103.7$, length $47 \mu \mathrm{m}$, interior view of operculum. 


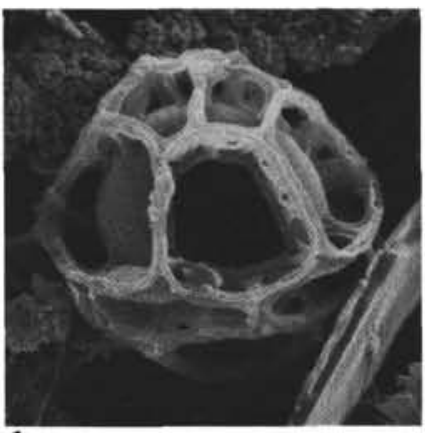

1

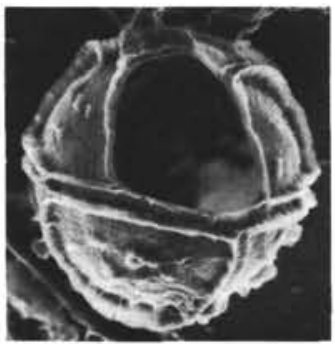

4

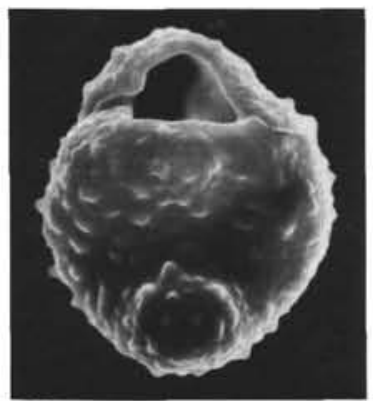

$8 \mathrm{~A}$

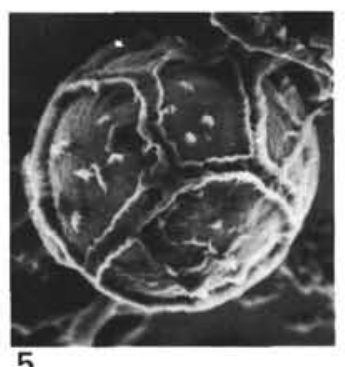

5

8B

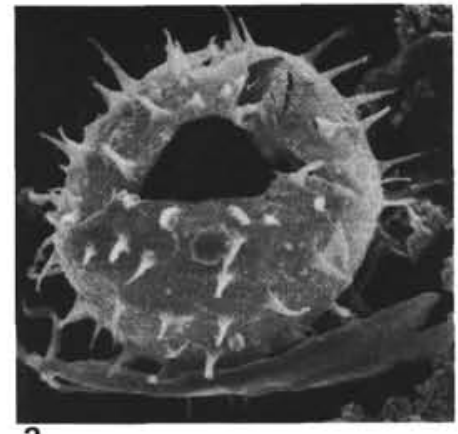

2

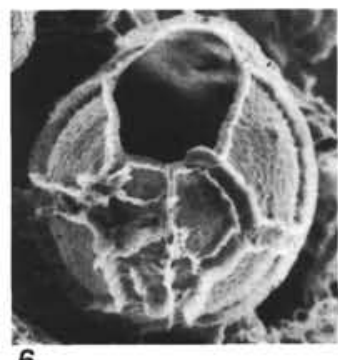

6

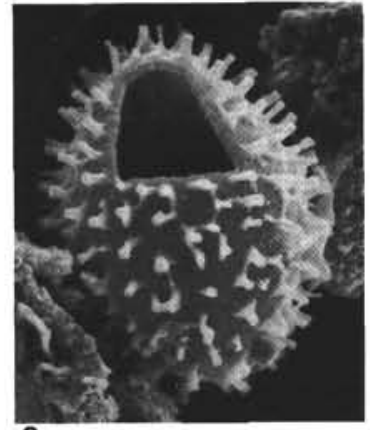

3

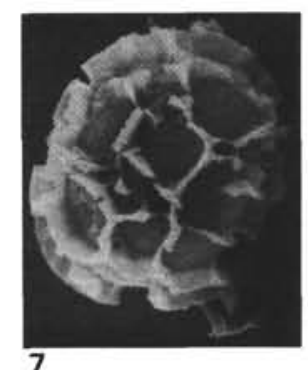

7
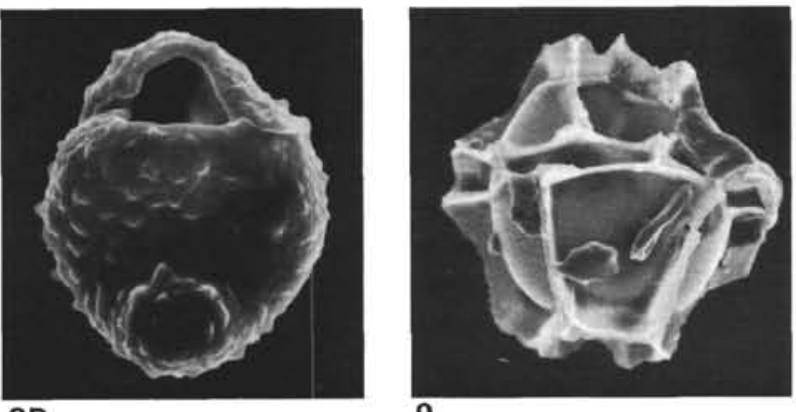

9
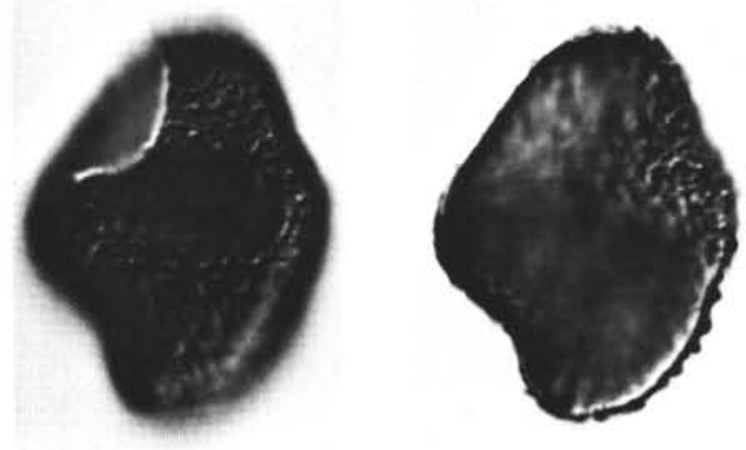

$10 \mathrm{~B}$

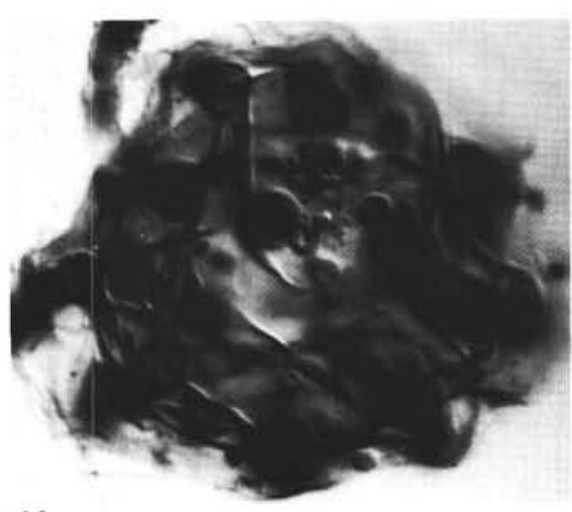

11

Plate 5. 1. "Nematosphaeropsis" aquaeducta Piasecki, 1980. Sample 555-22-1, 107-109 cm, R 2712 AV, dorsal view, length $47 \mu \mathrm{m}, \mathrm{SEM} . \quad 2$. Operculodinium centrocarpum (Deflandre and Cookson, 1955) Wall, 1967. Sample 555-22-1, 107-109 cm, R 2712 AV, dorsal view, max. diam. $70 \mu \mathrm{m}$, SEM. 3. Operculodinium sp. of Piasecki, 1980. Sample 555-22-1, 107-109 cm, R $2712 \mathrm{AV}$, dorsal view, length $47 \mu \mathrm{m}$, SEM. 4. Danea? sp. Sample 555-21-2, 60-62 cm, R $2712 \mathrm{AW}$, dorsal view, diam. $75 \mu \mathrm{m}$, SEM. 5. Danea? sp. Sample 555-21-2, 60-62 cm, R $2712 \mathrm{AW}$, antapical view, same specimen as 4, diam. $75 \mu \mathrm{m}$, SEM. 6. Danea? sp. Sample 555-21-2, 60-62 cm, R 2712 AW, apical view, diam. $73 \mu \mathrm{m}$, SEM. 7. "Gen. et sp. indet." of Piasecki, 1980. Sample 555-22-1, 107-109 cm, R 2712 AV, orientation uncertain, diam. $36 \mu \mathrm{m}$, SEM. 8. Tectatodinium simplex (Harland, 1979) n. comb. Sample 555-22-1, 107-109 cm, R $2712 \mathrm{AV}$, dorsal views, stereopair, length $45 \mu \mathrm{m}$, SEM. 9. Spiniferitesgroup sp. I. Sample 555-22-1, $107-109 \mathrm{~cm}, \mathrm{R} 2712 \mathrm{AV}$, dorsal view, length $67 \mu \mathrm{m}$, SEM. 10. Tectatodinium simplex (Harland, 1979) n. comb. Sample 555-22-1, 107-109 cm, R 2712 AV (1), 30.4 × 78.6 length $52 \mu \mathrm{m}$, right-lateral views, (A) right-lateral surface, (B) optical section. 11. Tuberculodinium vancampoae (Rossignol, 1962) Wall, 1967. Sample 555-22-1, 107-109 cm, R 2712 AV (1), $25.8 \times 80.7$, max. diam. $72 \mu \mathrm{m}$, ?antapical view. 